\title{
Quantifying the relative importance of greenhouse gas emissions from current and future savanna land use change across northern Australia
}

\author{
Mila Bristow ${ }^{1,2}$, Lindsay B. Hutley ${ }^{1}$, Jason Beringer ${ }^{3}$, Stephen J. Livesley ${ }^{4}$, Andrew C. Edwards ${ }^{1}$, and \\ Stefan K. Arndt ${ }^{4}$ \\ ${ }^{1}$ School of Environment, Research Institute for the Environment and Livelihoods, Charles Darwin University, \\ NT, 0909, Australia \\ ${ }^{2}$ Department of Primary Industry and Fisheries, Berrimah, NT, 0828, Australia \\ ${ }^{3}$ School of Earth and Environment, The University of Western Australia, Crawley, WA, 6009, Australia \\ ${ }^{4}$ School of Ecosystem and Forest Sciences, The University of Melbourne, Burnley, Victoria, 3121, Australia \\ Correspondence to: Lindsay B. Hutley (lindsay.hutley@cdu.edu.au)
}

Received: 15 May 2016 - Published in Biogeosciences Discuss.: 19 May 2016

Revised: 22 September 2016 - Accepted: 22 September 2016 - Published: 23 November 2016

\begin{abstract}
The clearing and burning of tropical savanna leads to globally significant emissions of greenhouse gases (GHGs); however there is large uncertainty relating to the magnitude of this flux. Australia's tropical savannas occupy the northern quarter of the continent, a region of increasing interest for further exploitation of land and water resources. Land use decisions across this vast biome have the potential to influence the national greenhouse gas budget. To better quantify emissions from savanna deforestation and investigate the impact of deforestation on national GHG emissions, we undertook a paired site measurement campaign where emissions were quantified from two tropical savanna woodland sites; one that was deforested and prepared for agricultural land use and a second analogue site that remained uncleared for the duration of a 22-month campaign. At both sites, net ecosystem exchange of $\mathrm{CO}_{2}$ was measured using the eddy covariance method. Observations at the deforested site were continuous before, during and after the clearing event, providing high-resolution data that tracked $\mathrm{CO}_{2}$ emissions through nine phases of land use change. At the deforested site, post-clearing debris was allowed to cure for 6 months and was subsequently burnt, followed by extensive soil preparation for cropping.

During the debris burning, fluxes of $\mathrm{CO}_{2}$ as measured by the eddy covariance tower were excluded. For this phase, emissions were estimated by quantifying on-site biomass prior to deforestation and applying savanna-specific emission
\end{abstract}

factors to estimate a fire-derived $\mathrm{GHG}$ emission that included both $\mathrm{CO}_{2}$ and non- $\mathrm{CO}_{2}$ gases. The total fuel mass that was consumed during the debris burning was $40.9 \mathrm{Mg} \mathrm{Cha}^{-1}$ and included above- and below-ground woody biomass, course woody debris, twigs, leaf litter and $\mathrm{C}_{4}$ grass fuels. Emissions from the burning were added to the net $\mathrm{CO}_{2}$ fluxes as measured by the eddy covariance tower for other postdeforestation phases to provide a total GHG emission from this land use change.

The total emission from this savanna woodland was 148.3 $\mathrm{Mg} \mathrm{CO}_{2}-\mathrm{e} \mathrm{ha}^{-1}$ with the debris burning responsible for $121.9 \mathrm{MgCO}_{2}-\mathrm{e} \mathrm{ha}^{-1}$ or $82 \%$ of the total emission. The remaining emission was attributed to $\mathrm{CO}_{2}$ efflux from soil disturbance during site preparation for agriculture $(10 \%$ of the total emission) and decay of debris during the curing period prior to burning ( $8 \%$ ). Over the same period, fluxes at the uncleared savanna woodland site were measured using a second flux tower and over the 22-month observation period, cumulative net ecosystem exchange (NEE) was a net carbon sink of $-2.1 \mathrm{MgC} \mathrm{ha}^{-1}$, or $-7.7 \mathrm{MgCO}_{2}$-e ha- ${ }^{-1}$.

Estimated emissions for this savanna type were then extrapolated to a regional-scale to (1) provide estimates of the magnitude of GHG emissions from any future deforestation and (2) compare them with GHG emissions from prescribed savanna burning that occurs across the northern Australian savanna every year. Emissions from current rate of annual savanna deforestation across northern Australia was double 
that of reported (non- $\mathrm{CO}_{2}$ only) savanna burning. However, if the total GHG emission, $\mathrm{CO}_{2}$ plus non- $\mathrm{CO}_{2}$ emissions, is accounted for, burning emissions are an order of magnitude larger than that arising from savanna deforestation. We examined a scenario of expanded land use that required additional deforestation of savanna woodlands over and above current rates. This analysis suggested that significant expansion of deforestation area across the northern savanna woodlands could add an additional $3 \%$ to Australia's national GHG account for the duration of the land use change. This bottom-up study provides data that can reduce uncertainty associated with land use change for this extensive tropical ecosystem and provide an assessment of the relative magnitude of GHG emissions from savanna burning and deforestation. Such knowledge can contribute to informing land use decision making processes associated with land and water resource development.

\section{Introduction}

An increase in greenhouse gas (GHG) emissions through human-related activities is leading to rapid change in the climate system (IPCC, 2013). It is, therefore, crucial to obtain data describing the net GHG balance at regional to global scales to better characterise anthropogenic forcing of the atmosphere (Tubiello et al., 2015). Emissions from land use change (LUC) are the integral of ecosystem transformations that can include emissions from deforestation and conversion to agriculture, logging and harvest activity, shifting cultivation, as well as regrowth sinks following harvest and/or abandonment of previously cleared agriculture lands (Houghton al., 2012). At present, LUC emits $0.9 \pm 0.5 \mathrm{Pg} \mathrm{Cyr}^{-1}$ to the atmosphere, which is approximately $10 \%$ of anthropogenic carbon emissions (Le Quéré et al., 2014). Data sources and methods used to estimate LUC emissions are diverse. These include census-based historical land use reconstructions and land use statistics, satellite estimates of biomass change through time (Baccini et al., 2012), satellite-monitored fire activity and burn area estimates associated with deforestation (van der Werf et al., 2010). In addition, there is increasing use of ecosystem models coupled with remote sensing to estimate emissions from LUC (Galford et al., 2011).

Emissions associated with the LUC sector have the highest degree of uncertainty given the complexity of processes involving net emissions and Houghton et al. (2012) assessed this uncertainty at $\sim 0.5 \mathrm{PgC} \mathrm{yr}^{-1}$, which is of the same order of magnitude as the emissions themselves. Uncertainties in estimating GHG emissions arising from savanna clearing, associated debris burning and conversion to agriculture are greater than those for tropical forests (Fearnside et al., 2009). It is important to quantify the emissions and their uncertainties in savannas, particularly because tropical savanna woodland and grasslands occupy a large area globally (27.6 million $\mathrm{km}^{2}$ ), greater than tropical forest (17.5 million $\mathrm{km}^{2}$, Grace et al., 2006). Deforestation and associated fire from these biomes are the largest contributors to global LUC emissions (Le Quéré et al., 2014). Much of these GHG emissions are from the Brazilian Amazonia, an agricultural area that has been expanding since the 1990s. However, over the last decade, the rate of tropical forest deforestation in this region has decreased from $16000 \mathrm{~km}^{2}$ in the early 2000 s to $\sim 6500 \mathrm{~km}^{2}$ by 2010 (Lapola et al., 2014), but at the expense of the Brazilian Cerrado, a vast savanna biome of some 2.04 million $\mathrm{km}^{2}$, where clearing rates have been maintained (Ferreira et al., 2013, 2016; Galford et al., 2013). Given the suitability of the Cerrado topography and soils for mechanised agriculture, the Cerrado may become the principal region of LUC in Brazil (Lapola et al., 2014).

Northern Australia is one of the world's major tropical savanna regions, extending some 1.93 million $\mathrm{km}^{2}$ across north-western Western Australia, the northern half of the Northern Territory and Queensland (Fisher and Edwards, 2015). This biome occupies approximately one quarter of the Australian continent and since European arrival, $5 \%$ has been cleared for improved pasture, horticulture and cropping (Landsberg et al. 2011), making it one of least disturbed savanna regions in the world (Woinarski et al., 2007). However, this small percentage equates to a substantial area of 9.2 million ha, and LUC and associated economic development in northern Australia is a government imperative and this is likely to involve expansion and intensification of grazing, irrigated cropping, horticulture and forestry (Committee on Northern Australia, 2014). Drivers of this potential expansion in food and fibre production include the exploitation of the growing markets of Asia as well as domestic factors such as the perception that land and water resources of northern Australia can provide a future agricultural resource base to offset the expected declines in agricultural productivity in southern Australia due to adverse impacts of climate change (Steffan and Hughes, 2013).

Historically, intensive agricultural developments in northern Australia have been implemented based on limited scientific knowledge with dysfunctional policy and market settings, and as a result there has been limited success (Cook, 2009). Future expansion needs to be underpinned by sound understanding of the consequences of regional-scale land transformation on carbon and water budgets and GHG emissions. Any significant expansion in northern agricultural production would require clearance of native savanna vegetation, with unknown increases in GHG emissions. Most LUC studies occur at catchment, regional or biome scales (Houghton et al., 2012) and are not underpinned by good understanding of underlying processes. However, there are an increasing number of plot-scale studies using eddy covariance and chamber methods to provide direct measures of net GHG fluxes from contrasting land uses (Lambin et al., 2013). These studies typically compare microclimate and fluxes of GHGs from pastures and/or crops with adjacent for- 
est ecosystems under a range of management conditions (e.g. Anthoni et al., 2004; Zona et al., 2013) or natural grasslands and different cropping types (e.g. Zenone et al., 2011). In tropical regions, there is a focus on transitions from forest to pasture and from forest to crops for food or bioenergy production (Galford et al., 2011; Wolf et al., 2011; Sakai et al., 2004).

There are few studies that directly measure GHG emissions and sinks prior to, during and after LUC at a single site. Land use change can involve rapid changes in net GHG emissions over varying temporal scales (minutes, hours and seasonal cycles) and continuous flux measurements are essential to capture the magnitude of these events (Hutley et al., 2005). However, there are no direct observations of emissions from savanna clearing in northern Australia, contributing to the uncertainty associated with the LUC sector in Australia's national GHG accounts (Commonwealth of Australia, 2015a).

Our objective is to provide a comprehensive assessment of GHG emissions associated with savanna clearing. Our aims are to (1) quantify the typical rates of $\mathrm{CO}_{2}$ exchange of intact tropical savanna and make comparative measurements from an analogue site that was to be cleared, (2) quantify $\mathrm{CO}_{2}$ fluxes before, during and after a clearing event, (3) estimate both $\mathrm{CO}_{2}$ and non- $\mathrm{CO}_{2}\left(\mathrm{CH}_{4}\right.$ and $\left.\mathrm{N}_{2} \mathrm{O}\right)$ GHG emissions arising from burning of cleared debris and (4) quantify ecosystem-scale GHG balance for this land use conversion and compare it with emissions from savanna fire, a significant source of GHG emissions across northern Australia.

\section{Methods}

In this study we used a paired site approach, where concurrent fluxes of $\mathrm{CO}_{2}$, water vapour and energy were measured using eddy covariance towers from an uncleared savanna woodland site and a similar savanna woodland site on the same soil type that was to be cleared, burnt and prepared for agricultural production. Fluxes of $\mathrm{CO}_{2}$ were monitored for 161 days prior to clearing at both sites with observations continuing during the clearing event (deforestation) and for another 507 days through phases of woody debris and grass curing, burning and soil preparation through raking and ploughing. The entire observation period was 668 days. Flux observations of net $\mathrm{CO}_{2}$ exchange were combined with on-site biomass measurements and regionally calibrated pyrogenic emissions factors to estimate emissions of $\mathrm{CO}_{2}, \mathrm{CH}_{4}$ and $\mathrm{N}_{2} \mathrm{O}$ (Meyer et al., 2012; Commonwealth of Australia, $2015 b$ ) from burning of the cleared debris that was a key component of the land conversion. Fire-derived emissions were combined with net $\mathrm{CO}_{2}$ fluxes from the land conversion phases to provide a total net emission in units of $\mathrm{CO}_{2}-\mathrm{e}$ for this LUC. In this paper, we use the term "deforestation" to describe savanna clearing. Deforestation is defined under Australia's National Greenhouse Accounts as the loss of forest/woodland cover due to direct human-induced actions that fail to regenerate cover via natural regrowth or restoration planting (Commonwealth of Australia, 2015a).

\subsection{Study sites}

Both savanna woodland sites were located within the Douglas-Daly river catchment approximately $300 \mathrm{~km}$ south of Darwin, Northern Territory (Fig. 1). Both sites are OzFlux sites (www.ozflux.org.au), with flux observations ongoing at the uncleared savanna (UC) site since 2007 (Beringer et al., 2011, 2016a; Hutley et al., 2011). OzFlux is the regional Australian and New Zealand flux tower network that aims to provide continental-scale monitoring of $\mathrm{CO}_{2}$ fluxes and surface energy balance to assess trends and improve predictions of Australia's terrestrial biosphere and climate (Beringer et al., 2016a). The UC site is broadly representative of Australian tropical savanna woodland found on deep, well drained sandy loam soils at sites with $\sim 1000 \mathrm{~mm}$ MAP (Table 1). The cleared savanna site (CS) was carefully selected to ensure the vegetation and soils were as similar to the UC site as possible and with topography suitable for eddy covariance measurements.

Both sites were classified as savanna woodland (type 4B2, Aldrick and Robinson 1972, 1:50000 mapping) with an overstorey cover of $30 \%$, equivalent to the Eucalypt woodland Major Vegetation Group (MVG) of the National Vegetation Information System (NVIS, Commonwealth of Australia, 2003). The sites were dominated by an overstorey of Eucalyptus tetrodonta (F. Muell.), Corymbia latifolia (F. Muell.). Soils at both the UC and CS sites were red kandosols of the haplic mesotrophic great group (Isbell, 2002), characterised as deep, sandy loams (Table 1). The long-term mean annual precipitation (MAP) $( \pm S D)$ at the UC site was estimated at $1180 \pm 225 \mathrm{~mm}$ (1970-2012, Australian Water Availability Project (AWAP), www.csiro.au/awap), similar to the CS site at $1107 \pm 342 \mathrm{~mm}$ (1985-2013, Bureau of Meteorology station, Tindal, NT). Slopes at both sites were $<2 \%$ with a fetch of $\sim 1.5 \mathrm{~km}$ at the UC site and $\sim 1 \mathrm{~km}$ at the CS site. At both sites, $23 \mathrm{~m}$ guyed masts were installed to support eddy covariance instruments at $21.5 \mathrm{~m}$ above-ground. The tower at the CS site was moved 3 times to ensure adequate fetch was maintained according to seasonal wind direction during clearing and phases of the land use conversion. Instrument height was also adjusted given the height of the surface post-clearing and during the soil tillage phase (Table 2).

Satellite-derived burnt area mapping is available across northern Australia at $250 \mathrm{~m}$ resolution (North Australian Fire Information system, NAFI, www.firenorth.org.au) and indicated that fires had occurred within the flux footprint of the UC flux tower in 5 out of the last 13 years (2000-2013), whereas no fires had occurred within the footprint of the CS site. The average fire return time for the entire Australian savanna biome is 3.1 years (Beringer et al., 2015). 


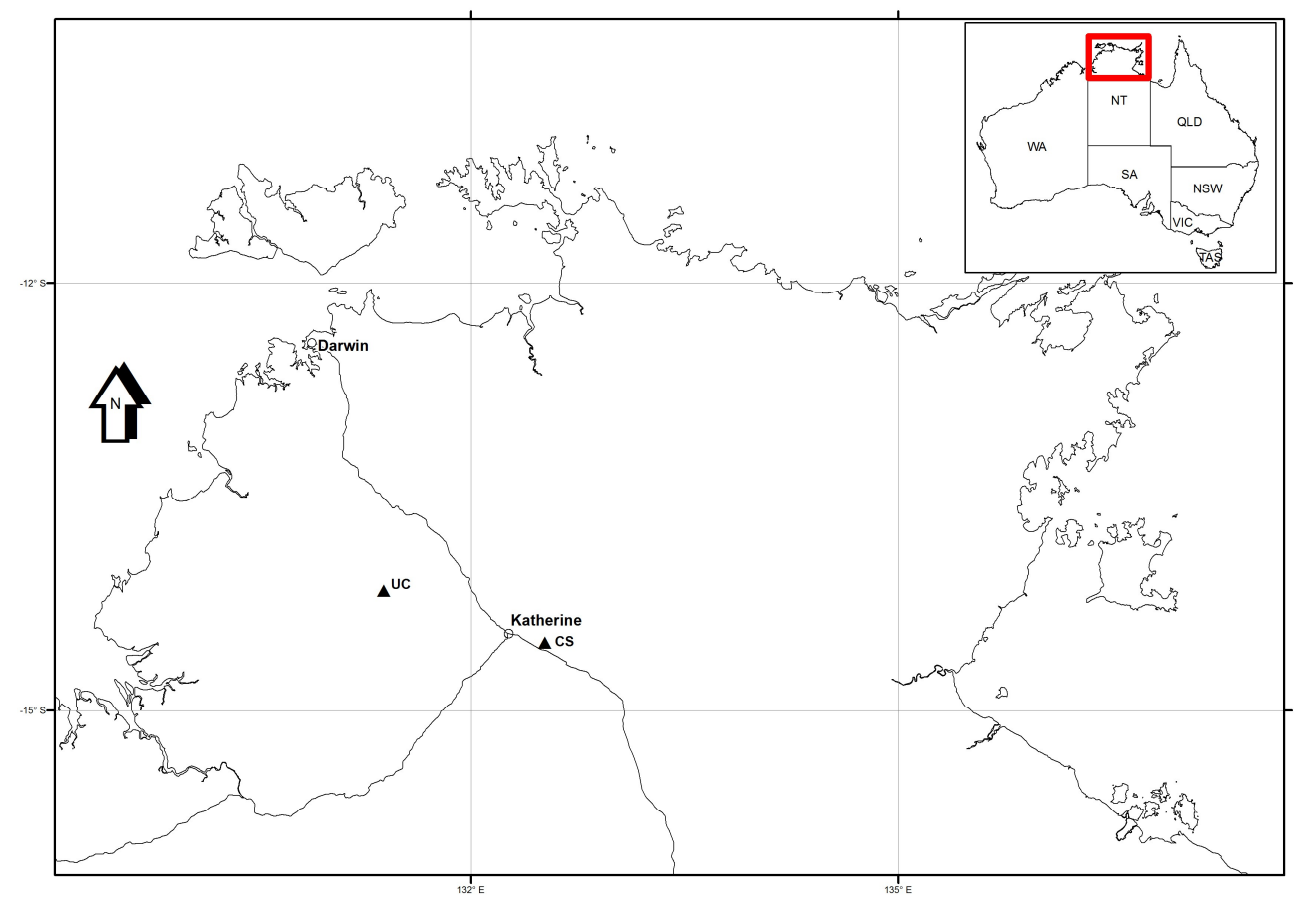

Figure 1. Location of the uncleared site (UC) and the cleared savanna (CS) sites south of Darwin, Northern Territory. The inset figure shows the distribution of the savanna biome across northern Australia as defined by Fox et al. (2001).

Table 1. Site characteristics for the uncleared savanna (UC) and cleared (CS) sites. Site soil orders are given as in Isbell (2002) with savanna vegetation classified using Fox et al. (2001). Fire frequency was estimated from fire mapping taken from the North Australian Fire Information system (NAFI, www.firenorth.org.au) for 2000-2012. The fire frequency estimate for the CS site excluded the debris fires in August 2012. Basal area and stem density is provided for all woody stems $>2 \mathrm{~cm} \mathrm{DBH}$ at both sites. Mean site LAI for the UC is taken from Hutley et al. (2011) and for the CS site, was estimated from canopy hemispherical photos, see text for details.

\begin{tabular}{lll}
\hline Site & $\mathrm{UC}$ & $\mathrm{CS}$ \\
\hline Location & $14^{\circ} 09^{\prime} 33.12^{\prime \prime} \mathrm{S}, 131^{\circ} 23^{\prime} 17.16^{\prime \prime} \mathrm{E}$ & $14^{\circ} 33^{\prime} 48.71^{\prime \prime} \mathrm{S}, 132^{\circ} 28^{\prime} 39.47^{\prime \prime} \mathrm{E}$ \\
Soils & Red Kandosol & Red Kandosol \\
Vegetation type & Savanna woodland with mixed grasses & Savanna woodland with mixed grasses \\
& Map unit D4. E. tetrodonta, C. latifolia, & Map unit D4. E. tetrodonta, Ery- \\
& Terminalia grandiflora, Sorghum spp., & throphleum chlorostachys, Corymbia. \\
& Heteropogon triticeus & bleeseri, Sorghum spp., H. triticeus \\
Map unit area $\left(\mathrm{km}^{2}\right)$ & 59986 & 59986 \\
Fire frequency $\left(\mathrm{yr}^{-1}\right)$ & 0.23 & 0.07 \\
Basal area $\left(\mathrm{m}^{2} \mathrm{ha}^{-1}\right)$ & 8.3 & 6.8 \\
Canopy height $(\mathrm{m})$ & 16.4 & 14.2 \\
Above-ground biomass $\left(\mathrm{Mg} \mathrm{Cha}{ }^{-1}\right)$ & $30.6 \pm 9.2$ & $26.2 \pm 7.0$ \\
Stem density $\left(\mathrm{ha}^{-1}\right)$ & $330 \pm 58$ & $643 \pm 102$ \\
Overstorey LAI (wet/dry) & NA/0.8 & $0.9 / 0.5$ \\
MODIS LAI (wet/dry) & $1.5 / 0.9$ & $1.6 / 1.0$ \\
MAP $(\mathrm{mm})$ & $1372^{\mathrm{a} / 1180^{\mathrm{b}}}$ & $1107^{\mathrm{c}}$ \\
Max $T_{\text {air }}\left({ }^{\circ} \mathrm{C}\right)$ & $37.5(\mathrm{Oct}) / 31.2(\mathrm{Jun})$ & $37.5(\mathrm{Oct}) / 29.7$ (Jun) \\
Min $T_{\text {air }}\left({ }^{\circ} \mathrm{C}\right)$ & $23.8(\mathrm{Jan}) / 12.6$ (Jul) & $25.0(\mathrm{Nov}) / 13.7$ (Jul)
\end{tabular}

${ }^{\mathrm{a}}$ On-site observations, 2007-2012. ${ }^{\mathrm{b}}$ Gridded precipitation (AWAP, 1970-2012). ${ }^{\mathrm{c}}$ Tindal BoM station $\left(14.52^{\circ} \mathrm{S}, 132.38^{\circ} \mathrm{E}\right.$, data from 1985 to 2013 ). NA stands for not available. 


\subsection{Flux measurements and data processing}

Eddy covariance systems at both sites consisted of CSAT3 3D ultrasonic anemometers (Campbell Scientific Inc., Logan, USA) and a LI-7500 open-path $\mathrm{CO}_{2} / \mathrm{H}_{2} \mathrm{O}$ analyser (Licor Inc., Lincoln, USA). Flux variables were sampled at $10 \mathrm{~Hz}$ and covariances were stored every $30 \mathrm{~min}$. The LI-7500 gas analysers were calibrated at approximately 6-month interval for the duration of the data collection period and were highly stable. Mean daily rainfall, air temperature, relatively humidity, soil heat flux $\left(F_{\mathrm{g}}, \mathrm{W} \mathrm{m}^{-2}\right)$ and volumetric soil moisture $\left(\theta_{\mathrm{v}}, \mathrm{m}^{3} \mathrm{~m}^{-3}\right)$ from surface to $2.5 \mathrm{~m}$ depths were measured at both sites. The radiation balance was measured using a CNR4 net radiometer $\left(F_{\mathrm{n}}, \mathrm{W} \mathrm{m}^{-2}\right)$ (Kipp and Zonen, Zurich).

Thirty minute covariances were stored using data loggers (CR3000, Campbell Scientific, Logan), and data postprocessing and quality control was undertaken using the OzFluxQC system as described by Isaac et al. (2016). In this system, data are processed through three levels: Level 1 is the raw data as collected by the data logger, Level 2 are qualitycontrolled data and Level 3 are post-processed and corrected but not gap-filled data. Quality control measures at Level 2 include checks for plausible value ranges, spike detection and removal, manual exclusion of date and time ranges and diagnostic checks for all quantities involved in the calculations to correct the fluxes. Quality checks make use of the diagnostic information provided by the sonic anemometer and the infrared gas analyser. Level 3 post-processing includes 2-dimensional coordinate rotation, low- and high-pass frequency correction, conversion of virtual heat flux to sensible heat flux $\left(F_{\mathrm{h}}, \mathrm{W} \mathrm{m}^{-2}\right)$ and application of the WPL correction to the latent heat $\left(F_{\mathrm{e}}, \mathrm{W} \mathrm{m}^{-2}\right.$ and $\mathrm{CO}_{2}$ fluxes $\left(F_{\mathrm{c}}\right)$ (Isaac et al., 2016). Level 3 data also include the correction of the ground heat flux for storage in the layer above the heat flux plates (Mayocchi and Bristow, 1995).

Gap filling of meteorology and fluxes along with flux partitioning of net ecosystem exchange (NEE) into gross primary productivity (GPP) and ecosystem respiration $\left(R_{\mathrm{e}}\right)$ was performed on the Level 3 data using the Dynamic INtegrated Gap filling and partitioning for Ozflux (DINGO) system as described by Beringer et al. (2016b). In summary, DINGO gap fills meteorological variables (air temperature, specific humidity, wind speed and barometric pressure) using nearby Bureau of Meteorology (BoM, www.bom.gov.au) automatic weather stations that were correlated with tower observations. All radiation streams were gap-filled using a combination of MODIS albedo products (MOD09A1) and BoM gridded global solar radiation and gridded daily meteorology from the Australian Water Availability Project (AWAP) data set (Jones et al., 2009). Precipitation was gap-filled using either nearby BoM stations or AWAP data. Soil temperature and moisture were filled using the BIOS2 land surface model (Haverd et al., 2013) run for each site and forced with BoM or AWAP data. Energy balance closure was examined using standard plots of $F_{\mathrm{h}}+F_{\mathrm{e}}$ vs. $F_{\mathrm{n}}-F_{\mathrm{g}}$ using $30 \min$ flux data from both sites (data not shown). For the CS site, closure was examined using data grouped according to the nine LUC phases as given in Table 2 . For the UC site, all $30 \mathrm{~min}$ data from 2007 to 2015 were used.

Gap filling of fluxes was undertaken using DINGO, which uses an artificial neural network (ANN) model following Beringer et al. (2007). Model training uses gradient information in a truncated Newton algorithm. NEE and fluxes of sensible, latent and ground heat fluxes were modelled using the ANN with incoming solar radiation, VPD (vapour pressure deficit), soil moisture content, soil temperature, wind speed and MODIS EVI as inputs. The ustar threshold for each site was determined following Reichstein et al. (2005) and nighttime observations below the ustar threshold were replaced with ANN modelled values of $R_{\mathrm{e}}$ using soil moisture content, soil temperature, air temperature and MODIS EVI as inputs. The ANN $R_{\mathrm{e}}$ model was then applied to daylight periods to estimate daytime respiration and GPP was calculated as the difference between NEE and $R_{\mathrm{e}}$. For data collected at the CS site, a unique ANN model was developed for each LUC phase given the differing canopy and microclimatology of each phase. At each site, daily NEE, $R_{\mathrm{e}}$ and GPP were calculated for each day of each phase.

\subsection{Leaf area index}

Canopy leaf area index (LAI) at the CS site in the surrounding intact savanna was measured using a $180^{\circ}$ hemispherical lens (Nikon $10.5 \mathrm{~mm}, \mathrm{f} / 2.8$ ) after Macfarlane et al. (2007). Three savanna transects were photographed seasonally on nine occasions over 2.1 years from the preclearing phase (October 2011) to December 2013. Along each $100 \mathrm{~m}$ transect, 11 hemispherical pictures were taken at $10 \mathrm{~m}$ intervals (33 photos for each measure occasion). At both sites the LAI was also estimated using MODIS Collection 5 LAI (MOD15A2) for a $1 \mathrm{~km}$ pixel around each tower. The 8-day product was interpolated to daily time series using a spline fit. Only MODIS values with a quality flag of 0 for FparLai_QC were used in the estimate, indicating the main algorithm that was used (http://lpdaac.usgs.gov/sites/default/files/public/modis/ docs/MODIS-LAI-FPAR-User-Guide.pdf).

\subsection{Land use conversion}

The specific sequence and timing of clearing, burning and land preparation phases is given in Table 2. Conversion of woodland to agricultural land in northern Australia is typically achieved by pulling trees over using large chains held under tension between two bulldozers. Clearing occurs at the end of the wet season when soil moisture is still high and soil strength low as under these conditions trees are easily pulled over, with a large fraction of the tree root mass extracted when pulled. At the CS site, 295 ha of savanna were 
Table 2. Characteristics of land conversion phases during the 668-day observation period at the savanna clearing site (CS). Also given are the canopy heights following LUC phases and flux instrument heights that were adjusted following clearing, burning and then soil preparation phases.

\begin{tabular}{|c|c|c|c|c|}
\hline Season & Period & $\begin{array}{l}\text { LULUC } \\
\text { phases }\end{array}$ & $\begin{array}{r}\text { Canopy } \\
\text { height }(\mathrm{m})\end{array}$ & $\begin{array}{l}\text { Instrument } \\
\text { height }(\mathrm{m})\end{array}$ \\
\hline Late dry season & Sep-Oct 2011 & Intact savanna & 16 & 21.5 \\
\hline Wet season pre-clearing & Oct 2011-Feb 2012 & Intact savanna & 16 & 21.5 \\
\hline Wet season clearing & Mar-May 2012 & $\begin{array}{l}\text { Savanna deforested using bulldozers, followed by de- } \\
\text { bris decomposition, understory grass germination }\end{array}$ & 3 & 7 \\
\hline Dry season pre-burn & May-Aug 2012 & Vegetation debris curing, understorey grass growth & 2 & 7 \\
\hline Debris burning & Aug 2012 & $\begin{array}{l}\text { Debris and grasses burnt, soil ripped to } 60 \mathrm{~cm} \text { to remove } \\
\text { roots, roots and remaining debris stockpiled, reburnt }\end{array}$ & 2 & 7 \\
\hline Dry season post-burn & Aug-Nov 2012 & Grass and shrubs germination and resprouting & 1 & 7 \\
\hline Early wet season & Nov 2012-Jan 2013 & $\begin{array}{l}\text { Removal remaining below-ground biomass. Wet sea- } \\
\text { son rains stimulates grass growth, shrub resprouting and } \\
\text { growth }\end{array}$ & 1 & 7 \\
\hline Wet season & Jan-Mar 2013 & $\begin{array}{l}\text { All regenerated vegetation removed, soil bed prepara- } \\
\text { tion }\end{array}$ & 0 & 3 \\
\hline Dry season & Apr-Jul 2013 & Soil cultivation in stages & 0 & 3 \\
\hline
\end{tabular}

deforested between 2 and 6 March 2012 using this technique. A permit for this land conversion had been issued by the regional land management agency following an impact assessment and erosion control planning. Chains were under tension and intercepted tree boles at $0.1-0.2 \mathrm{~m}$ height above the ground, which assisted in pulling the trees and limited damage to the soil surface. As a result, grasses, woody resprouts and shrubs of the understorey remained largely intact following deforestation (Plate 1a). Mechanised ripping of soil to $60 \mathrm{~cm}$ depth was also undertaken to remove remaining coarse root material.

A cost-effective method of removing cleared vegetation is curing (drying) and subsequent burning and the land managers at the CS site left debris on site to for 5 months through the dry season (March to August, 2011). Burning of debris occurred over a 22-day period in the late dry season, August 2012 (Plate 1b), a period of consistent southerly trade winds of low relative humidity $(10-20 \%$, BoM, Tindal station, NT). Prior to ignition, $100 \mathrm{~m}$ fire breaks were installed around the entire 295 ha block and then lit in blocks of $\sim 80$ ha in size. There was an initial ignition of the fine and coarse fuels (grasses, litter and twigs, defined below) and woody debris (heavy fuels). Heavy fuels that were not completely consumed following the initial burn were then stock-piled in rows $\sim 1-2 \mathrm{~m}$ in height and reignited until the fuel was consumed (Plate 1c). Inspection of debris post- fire suggested $\sim 5 \%$ of fine fuels remained as ash and $\sim 10 \%$ of the heavy fuels remained as charcoal, and these were subsequently incorporated into the top soil during soil bed preparation (Plate 1d).

\subsection{GHG emissions from debris burning}

Emissions of $\mathrm{CO}_{2}, \mathrm{CH}_{4}$ and $\mathrm{N}_{2} \mathrm{O}$ from the debris burning were estimated following the approach as outlined in the IPCC Good Practice Guidelines (IPCC, 2003), which uses country or region-specific emission factors for fire activity (indicated by burnt area) and the mass of fuel pyrolysed to estimate the emission of each trace gas. This approach is well developed for the fire regime of the northern Australian savanna and is described by Russell-Smith et al. (2013) and Murphy et al. (2015a). These authors describe a novel GHG emissions abatement methodology for savanna burning that combines indigenous fire practices with an emissions accounting framework, the Emissions Abatement through Savanna Fire Management (Commonwealth of Australia, 2015b, www.comlaw.gov.au/Series/ F2013L01165). This methodology is a legislative instrument that establishes procedures for abatement projects for prescribed savanna burning and defines emission factors for four fuel classes; fine (grass and litter $<6 \mathrm{~mm}$ diameter fragments), coarse $(6 \mathrm{~mm}-5 \mathrm{~cm})$, heavy ( $>5 \mathrm{~cm}$ diameter) and shrubs fuels (Russell-Smith et al., 2013). Emissions of GHGs are estimated based on vegetation type, fuel mass per area for each fuel type, burn area, the burning efficiency (BEF) for each fuel type, defined as the mass of fuel exposed to fire that is pyrolysed, the fuel carbon content (\%), elemental $\mathrm{C}: \mathrm{N}$ ratios and emission factors (EFs) for each $\mathrm{GHG}\left(\mathrm{CO}_{2}\right.$, $\mathrm{CH}_{4}$ and $\mathrm{N}_{2} \mathrm{O}$ ) and global warming potentials for each gas. Across the northern Australian savanna, values for BEFs and EFs have been determined for both high ( $>1000 \mathrm{~mm}$ MAP) and low precipitation zones (1000-600 mm MAP) and for both early and late dry season fires, which are fires occurring after 1 August which typically have higher intensity and 

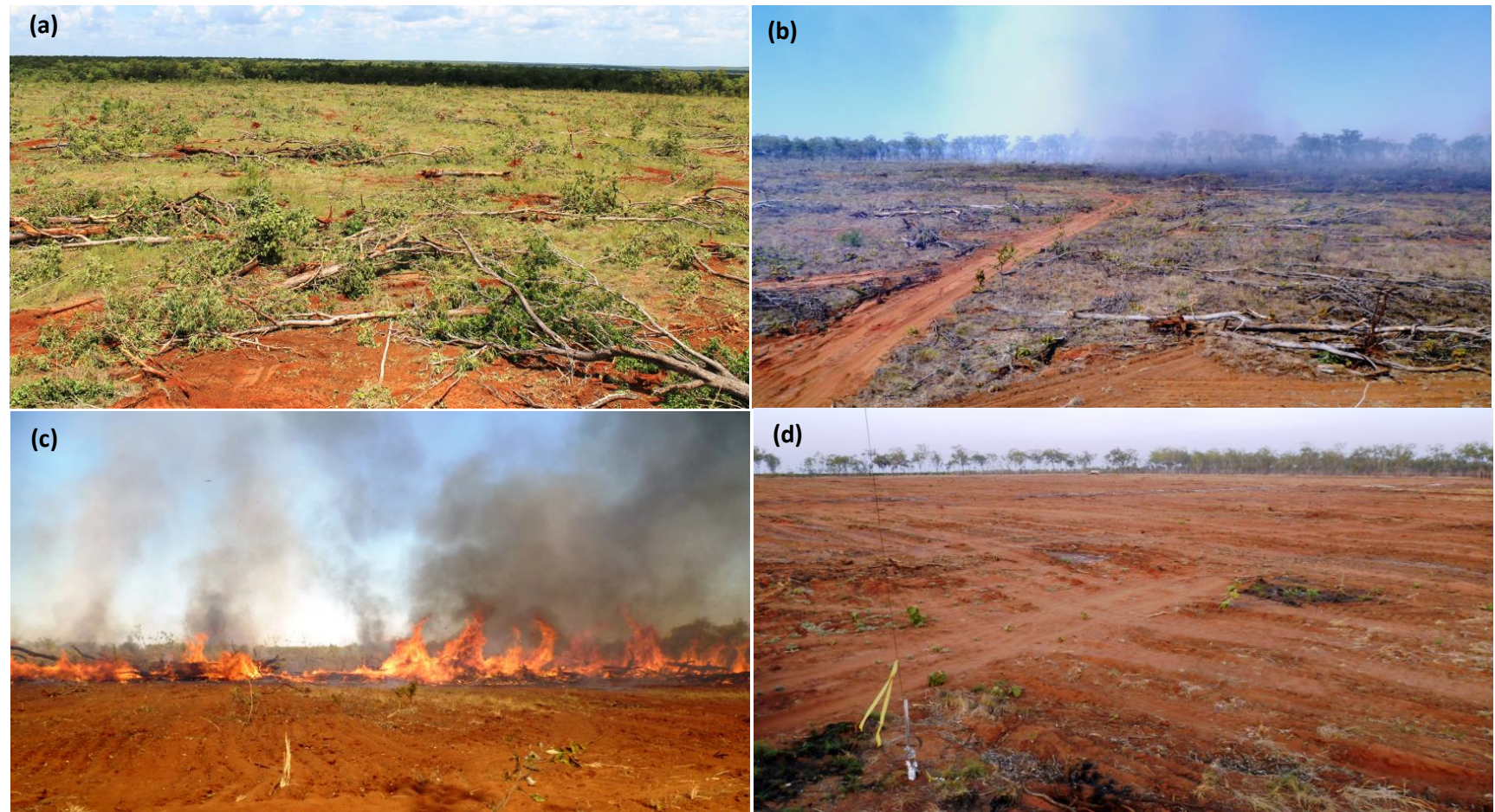

(d)

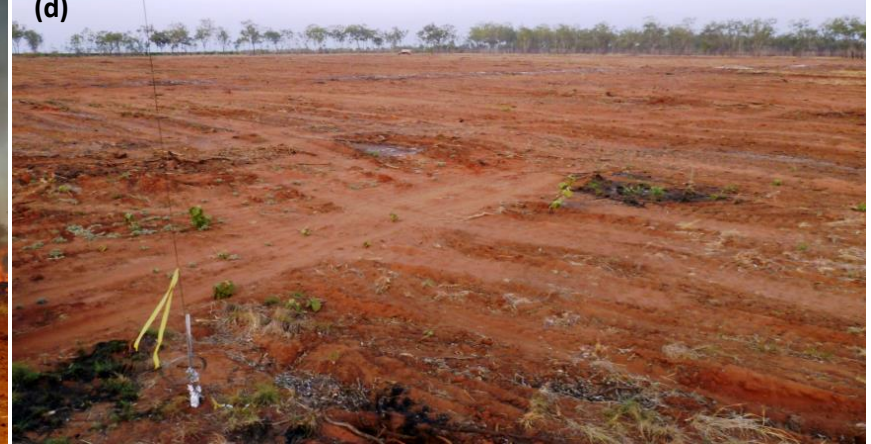

Plate 1. Key LUC phases associated with: (a) the clearing event, Phase 3; (b) debris burning of the cured grass, litter and woody fuels following the 5-month curing period, Phase 5; (c) stockpiling and ignition of remaining unburnt debris and (d) post-fire site preparation with all biomass consumed, Phase 9 .

combustion efficiencies than early dry season fires (RussellSmith et al., 2013).

We used these definitions of vegetation fuel type (woodland savanna with mixed grass) and associated EFs, carbon contents and $\mathrm{N}: \mathrm{C}$ ratio values as defined in the methodology to estimate GHG emissions from the debris fire using the following equation:

$E=\sum_{i}\left(\mathrm{FL}_{j} \times \mathrm{BEF}_{j} \times \mathrm{CC}_{j} \times \mathrm{N}: \mathrm{C}_{\mathrm{N}_{2} \mathrm{O}} \times \mathrm{EF}_{i, j} \times \mathrm{GWP}_{i}\right)$,

where $E$ is the sum of emissions in $\mathrm{MgCO}_{2}-\mathrm{eha}^{-1}$ for each GHG $i\left(\mathrm{CO}_{2}, \mathrm{CH}_{4}\right.$ and $\left.\mathrm{N}_{2} \mathrm{O}\right), \mathrm{FL}_{j}$ is the fuel load for fuel type $j$ (fine, coarse, heavy) in $\mathrm{MgCha}^{-1}, \mathrm{BEF}_{j}$ is the burning efficiency factor, $\mathrm{CC}_{j}$ is the fractional carbon content, $\mathrm{N}: \mathrm{C}_{\mathrm{N}_{2} \mathrm{O}}$ is the fuel nitrogen to carbon ratio for $\mathrm{N}_{2} \mathrm{O}$ emissions, $\mathrm{EF}_{i, j}$ is the emission factor for GHG $i$ and fuel type $j$, and $\mathrm{GWP}_{i}$ is the global warming potential for each GHG $i$ (after Commonwealth of Australia, 2015b). The debris fire differed from a typical savanna fire in that there was a significantly higher heavy fuel load present and it was of high intensity which consumed the vast majority of fuel (Plate 1c, d), reflected in the assumed BEFs we used. The fire-derived emissions were combined with tower-derived NEE data from the post-clearing phases (Table 3) to give a total emission in $\mathrm{CO}_{2}$-e for this LUC.

\subsection{Quantifying fuel loads}

To accurately quantify emissions from the debris fire, fine, coarse and heavy fuels were estimated using plots and transects established across the 295 ha deforestation area. For fine fuels, six $100 \mathrm{~m}$ transects were randomly located and at $20 \mathrm{~m}$ intervals along each transect, all fine (grass, woody litter) and coarse (twigs, sticks) fuels were harvested from $1 \mathrm{~m}^{2}$ quadrats, dried and weighed to give a mean fine and coarse fuel mass for the site. We assigned on-site coarse woody debris (CWD), above-ground and below-ground biomass estimates to the heavy fuel class ( $>5 \mathrm{~cm}$ diameter fragments). To quantify $\mathrm{CWD}$, an additional six $100 \mathrm{~m}$ transects were randomly located across the deforestation area and along each transect the length and diameter of all intersected CWD fragments were recorded to estimate fragment volume. In these savannas, large fragments $(>10 \mathrm{~cm}$ diameter) are frequently hollowed from the action of termites and fire and the diameter and length of the annulus of such fragments were measured to estimate this missing volume. In addition, large fragments that were tapered were treated as a frustum of a cone and a second diameter was taken at the fragment end to improve volume estimation. Fragment volumes were calculated and converted to mass using rot classes (RCs) and associated wood densities $\left(\mathrm{g} \mathrm{cm}^{-3}\right)$. Five rot classes (RCs) were defined and assigned to each CWD fragment to cap- 
Table 3. Cumulative precipitation and mean NEE, $R_{\mathrm{e}}$ and GPP $\left(\mathrm{MgCha}^{-1} \mathrm{month}^{-1}\right)$ for each of the LUC phases at the CS site as measured by the flux tower. These fluxes are given for the UC site for these same periods. One-way ANOVA was used to test for differences between mean daily NEE for each LUC phase with significantly different means labelled with an asterisk. On the days of ignition during the debris burning phase, flux data at the CS site were excluded. Integrated fluxes are given for the post-clearing period (507 days) and the entire observation period (668 days) for both sites in $\mathrm{MgCha}^{-1}$.

\begin{tabular}{|c|c|c|c|c|c|c|c|c|c|c|}
\hline \multirow[b]{2}{*}{ LULUC phases } & \multirow[b]{2}{*}{$\begin{array}{r}\text { Phase } \\
\text { number }\end{array}$} & \multirow[b]{2}{*}{$\begin{array}{r}\text { Period } \\
\text { (d) }\end{array}$} & \multicolumn{4}{|c|}{$\mathrm{CS}$} & \multicolumn{4}{|c|}{$\mathrm{UC}$} \\
\hline & & & $\begin{array}{r}\text { Rainfall } \\
(\mathrm{mm})\end{array}$ & \multicolumn{3}{|c|}{$\left(\mathrm{MgCha}^{-1}\right.$ month $\left.^{-1}\right)$} & $\begin{array}{r}\text { Rainfall } \\
(\mathrm{mm})\end{array}$ & \multicolumn{3}{|c|}{$\left(\mathrm{Mg} \mathrm{Cha}^{-1}\right.$ month $\left.^{-1}\right)$} \\
\hline Intact canopy cover & 1 & 161 & 736.6 & -0.23 & 1.57 & -1.79 & 1076.8 & -0.25 & 1.45 & -1.70 \\
\hline Clearing event & 2 & 4 & 59.4 & $0.23^{*}$ & 1.95 & -1.73 & 59.8 & $0.38^{*}$ & 1.80 & -1.50 \\
\hline Wet-dry debris curing, decomposition & 3 & 59 & 143.2 & $0.98^{* *}$ & 1.39 & -0.41 & 412.0 & $0.32^{* *}$ & 1.53 & -1.22 \\
\hline Dry season pre-burn & 4 & 94 & 0 & $0.34^{* *}$ & 0.57 & -0.23 & 2.4 & $0.15^{* *}$ & 0.94 & -0.79 \\
\hline Fire emissions late dry & 5 & 22 & 0 & $0.90^{* *}$ & 0.76 & 0.0 & 0.0 & $-0.01^{* *}$ & 0.71 & -0.72 \\
\hline Dry season post-burn & 6 & 67 & 2.2 & $0.31^{* *}$ & 0.37 & -0.06 & 64.4 & -0.28 & 0.64 & -0.91 \\
\hline Early wet regrowth & 7 & 80 & 361.0 & $0.03^{* *}$ & 0.99 & -0.96 & 345.8 & -0.32 & 1.80 & -2.12 \\
\hline Wet season site prep. & 8 & 91 & 701.7 & $0.62^{* *}$ & 0.99 & -0.37 & 914.4 & $-0.20 * *$ & 1.67 & -1.88 \\
\hline \multirow[t]{2}{*}{ Dry season final bed prep. and cultivation } & 9 & 90 & 0 & $0.29 * *$ & 0.32 & -0.02 & 10.8 & $0.06^{* *}$ & 0.91 & -0.85 \\
\hline & & & \multicolumn{4}{|c|}{$\left(\mathrm{MgCha}^{-1}\right)$} & & \multicolumn{3}{|c|}{$\left(\mathrm{MgCha}^{-1}\right)$} \\
\hline Total post-clearing & & 507 & 1267.5 & $7.2^{* *}$ & 12.8 & -5.6 & 1809.6 & $-0.78^{* *}$ & 20.7 & -21.5 \\
\hline Total all phases & & 668 & 2004.1 & $6.0^{* *}$ & 21.2 & -15.2 & 2886.4 & $-2.1^{* *}$ & 28.5 & -30.6 \\
\hline
\end{tabular}

* Denotes significantly different mean NEE at the $5 \%$ level, ${ }^{* *}$ significant at $1 \%$.

ture the decay gradient of fragments. These were defined as recently fallen, solid wood (RC1), solid wood with or without branches present but with signs of aging (RC2), obvious signs of weathering, still solid wood, bark may or may not be present (RC3), signs of decay with the wood sloughed and friable (RC4) and severely decayed fragments with little structural integrity remaining (RC5). A wood density was assigned to each RC and species (where identifiable) after Rose (2006) and Brown (1997) to provide an accurate estimate of CWD mass that included decay and hollowing. For the dominant Eucalyptus and Corymbia species wood densities ranged from $0.7 \mathrm{~g} \mathrm{~cm}^{-3}$ (RC1) to $0.56 \mathrm{~g} \mathrm{~cm}^{-3}$ (RC5).

Above-ground biomass was quantified by surveying all woody plants $>1.5 \mathrm{~m}$ in height or $>2 \mathrm{~cm} \mathrm{DBH}$ across eight $50 \times 50 \mathrm{~m}$ plots. All woody individuals were identified to species and stem diameter at $1.3 \mathrm{~m}$ height $(\mathrm{DBH})$ and tree height were measured. Region-specific allometric equations are available for tree species found at the CS site (Williams et al., 2005) and these were used to estimate above-ground biomass for each individual tree and shrub based on DBH and height. Below-ground biomass was calculated using the root / shoot ratio estimate of Eamus et al. (2002) for these savanna stands, which was 0.38 . These trees have large lateral roots in the top $30 \mathrm{~cm}$ of soil, with no tap root and $90 \%$ of root biomass is found in the top $50 \mathrm{~cm}$ of soil (Eamus et al., 2002). As such, we assumed that chaining and bulldozer clearing of all above-ground biomass followed by soil ripping (ploughing) to $60 \mathrm{~cm}$ soil depth, plus mechanised removal of root biomass associated with tree boles and subsequent burning, resulted in a near-complete removal of both above- and below-ground woody biomass pools (Plate 1d).

\subsection{Deforestation and savanna burning emissions at catchment to regional scales}

The potential impact of any expanded deforestation across the northern Australian savanna landscapes was assessed relative to historic deforestation rates and resultant GHG emissions and arising from prescribed savanna burning. This land management activity contributes $\sim 3 \%$ to Australia's national GHG emissions (Whitehead et al., 2014) and is $25 \%$ of the Northern Territory's annual emissions (Commonwealth of Australia, 2015a). Annual emissions from these activities (historic and future savanna deforestation and prescribed burning) were estimated at three spatial scales: (1) catchment, (2) state/territory and (3) regional. Emissions estimates from deforestation and savanna burning were compiled for (1) the Douglas-Daly river catchment where the UC and CS sites are located (area $57571 \mathrm{~km}^{2}$ ), a catchment with less than $5 \%$ of the native vegetation deforested to date (Lawes et al., 2015) but earmarked for future development; (2) the savanna area of Northern Territory $\left(856000 \mathrm{~km}^{2}\right)$ and (3) the savanna region of northern Australia as defined by Fox et al. (2001) with MAP $>600 \mathrm{~mm}$, an area of 1.93 million $\mathrm{km}^{2}$ (Fig. 1, insert).

Emissions of GHGs from historic deforestation from the Douglas-Daly catchment were estimated using our estimates for savanna land conversion combined with satellite-derived annual deforestation area (1990-2013) as reported by Lawes et al. (2015) for this catchment to give a catchment-scale mean annual estimate of emissions from deforestation in $\mathrm{Gg} \mathrm{CO}_{2}-\mathrm{e} \mathrm{yr}^{-1}$. Annual deforestation emissions data for the Northern Territory and the northern Australian savanna re- 
gion were taken from the National Greenhouse Gas Inventory (NGGI) for the same period 1990-2013. The Department of Environment is responsible for reporting sources of greenhouse gas emissions and removals by sinks in accordance with UNFCCC Reporting Guidelines on Annual Inventories and the supplementary reporting requirements under the Kyoto Protocol. State and Territory GHG Inventories are reported for 1990 to 2013 (Commonwealth of Australia, 2015a) and we used data for the Land Use, Land-Use Change and Forestry sector, Activity A.2 Deforestation. These emissions are reported for each state, but are not biome based and for our regional savanna estimate, emissions data for Western Australia, the Northern Territory and Queensland were used but were calculated using the area within each state that was defined as savanna by Fox et al. (2001, Fig. 1). Mean annual deforestation emissions from the savanna area of each state and territory (1990-2013) were summed to calculate a mean $( \pm \mathrm{SD})$ annual deforestation rate for the northern Australian savanna area (1.92 million $\mathrm{km}^{2}$ ) in $\mathrm{Gg} \mathrm{CO}_{2}$-e $\mathrm{yr}^{-1}$.

Emissions from savanna burning were calculated using the online Savanna Burning Abatement Tool (SAVBat2, www. savbat2.net.au) using the predefined vegetation fuel types (VFTs) mapping for the northern Australian savanna (Fisher and Edwards, 2015; Thackway, 2014), both components of the Emissions Abatement through Savanna Fire Management methodology. SAVBat2 combines satellite-derived burnt area mapping (www.firenorth.org.au) with fuel load estimates from VFT mapping, GHG emission factors and burn efficiencies to estimate annual emissions from burn areas. In accordance with IPCC accounting rules, only non- $\mathrm{CO}_{2}$ emissions are reported for savanna burning as it is assumed that $\mathrm{CO}_{2}$ emissions from dry season burning is offset by regrowth of vegetation (mostly $\mathrm{C}_{4}$ grasses) in subsequent wet season(s) (IPCC, 1997). However, for comparisons with deforestation emissions, we calculated emissions of $\mathrm{CO}_{2}$ as well as non- $\mathrm{CO}_{2}$ emissions. SAVBat2 estimates were compiled for the same areas as savanna deforestation estimates; the Douglas-Daly river catchment, savanna of the NT and the northern Australian savanna. Mean annual burning emissions for 1990-2013 were calculated and are reported as non$\mathrm{CO}_{2}\left(\mathrm{CH}_{4}, \mathrm{~N}_{2} \mathrm{O}\right)$ and total emissions $\left(\mathrm{CO}_{2}, \mathrm{CH}_{4}\right.$ and $\left.\mathrm{N}_{2} \mathrm{O}\right)$ in $\mathrm{Gg} \mathrm{CO}_{2}$-e $\mathrm{yr}^{-1}$.

\subsection{Emissions from expanded deforestation across northern Australia}

Emissions from expanded deforestation across northern Australia was estimated by upscaling our estimate of deforestation emissions per hectare from catchment areas identified as having future clearing potential. These areas were based on the land use assessment of northern Australian catchments by Petheram et al. (2014) and identified catchments with development potential based upon surface water storage and proximity of land resources suitable for irrigation development for agriculture, horticulture or improved pastures.
Using these criteria, suitable catchments were identified in Western Australia (Fitzroy River, Ord Stage 3; 75000 ha potential area), the Northern Territory (Victoria, Roper Rivers, Ord Stage 3, Darwin-Wildman River area; 114500 ha) and Queensland (Archer, Wenlock, Normanby, Mitchel Rivers; $120000 \mathrm{ha}$ ). This gives a potential savanna deforestation area of 311000 ha, equivalent to an additional $16 \%$ of cleared land over and above the 1886512 ha that has been cleared across the savanna biome since 1990 (Commonwealth of Australia, 2015a). Projected emissions included mean annual emissions from historic deforestation rates plus emissions from this expanded deforestation scenario. Expanded deforestation areas were calculated assuming any such clearing would occur over a 5-year period and are reported as non$\mathrm{CO}_{2}\left(\mathrm{CH}_{4}, \mathrm{~N}_{2} \mathrm{O}\right)$ and total emissions $\left(\mathrm{CO}_{2}, \mathrm{CH}_{4}\right.$ and $\left.\mathrm{N}_{2} \mathrm{O}\right)$ in $\mathrm{Gg} \mathrm{CO}_{2}-\mathrm{e} \mathrm{yr}^{-1}$.

\section{Results}

\subsection{Pre-clearing site comparisons}

Pre-clearing meteorology, flux observations and energy balance closure for UC and CS sites were compared (Fig. 2). Mean monthly NEE, $R_{\mathrm{e}}$ and GPP for each LUC phase for both sites are given in Table 3. Flux measurements prior to clearing were made for 161 days, a period spanning the late dry to early wet season transition (September-December) through to the middle of the wet season (January-February, Table 2). Flux data at the CS site were validated by assessing energy balance closure, with a regression between energy balance components suggesting closure was high with a slope of 0.91 and an $R^{2}$ of $0.95(n=4778)$. Site differences for each phase were tested using one-way ANOVA using daily mean NEE with days as replicates. For Phase 1, mean daily NEE was not significantly different between the two sites during $(P<0.64, \mathrm{~d} f=321)$. Seasonal patterns of $T_{\text {air }}$, VPD (Fig. 2b), LAI (Fig. 2c) and C fluxes (NEE, GPP, $R_{\mathrm{e}}$, Fig. 2d) were similar when both sites were intact, although precipitation was $340 \mathrm{~mm}$ higher at the UC site (Table 3).

At both sites, NEE shifted from being a weak sink of less than $-1 \mu \mathrm{mol} \mathrm{CO}_{2} \mathrm{~m}^{-2} \mathrm{~s}^{-1}$ during the late dry season to a net source of $\mathrm{CO}_{2}$ during the early wet season (Fig. 2d). During this period, $R_{\mathrm{e}}$ increased rapidly from +2 to $+5 \mu \mathrm{mol} \mathrm{m} \mathrm{m}^{-2} \mathrm{~s}^{-1}$ in early October with the onset of wet season rain, but then remained relatively constant for the remainder of the wet season. As the wet season progressed, temporal patterns of GPP were similar at both sites, then steadily increased to -6 to $-7 \mu \mathrm{mol} \mathrm{m} \mathrm{m}^{-2} \mathrm{~s}^{-1}$ and remained at this rate until they cleared (March 2012). $R_{\mathrm{e}}$ was relatively stable during this period and NEE increased to $-2 \mu \mathrm{mol} \mathrm{m}{ }^{-2} \mathrm{~s}^{-1}$ through the wet season (December to February). Despite the higher precipitation received at the UC site, mean monthly NEE, GPP and $\mathrm{R}_{e}$ differed by $<10 \%$ (Table 3 , intact canopy phase). Normalising fluxes by MODIS LAI for each site fur- 


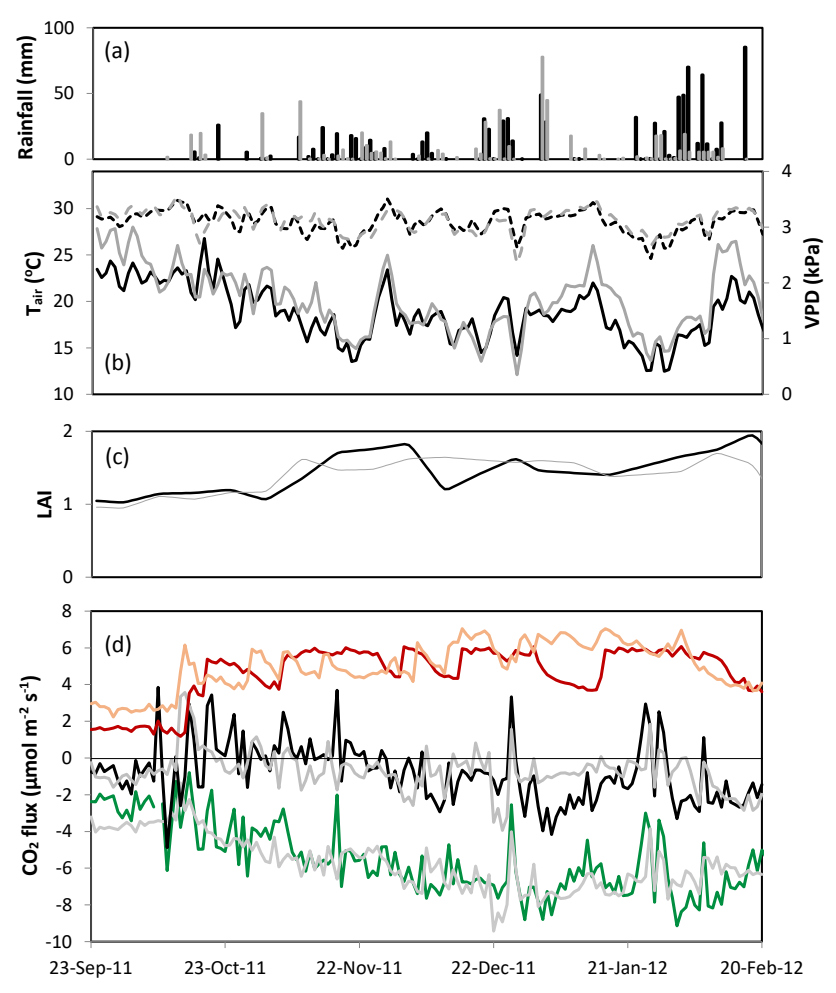

Figure 2. Comparative meteorology and fluxes for the uncleared (UC) and cleared savanna CS sites prior to the clearing event. Data spans the late dry season (September 2011) through to the middle of the wet season prior to the clearing event of 2-6 March 2012. Plots include (a) daily precipitation (black bars UC site, grey bars CS site), mean daily $T_{\text {air }}$ (black lines UC, grey CS), (b) mean daily VPD (dashed lines; black UC, grey CS), (c) interpolated 8-day MODIS LAI (black UC, grey CS), (d) NEE (black UC, grey CS) partitioned into $R_{\mathrm{e}}$ (red UC, pink CS) and GPP (dark green UC, pale green $\mathrm{CS}$ ).

ther reduced differences to $2 \%$ (data not shown), suggesting site differences were small and the UC site provides a suitable control for the CS site.

\subsection{Fluxes following clearing}

Clearing of the 295 ha block commenced on 2 March 2012 and the bulldozers reached the footprint of the flux tower at $\sim$ 09:00 h local time on 6 March (Fig. 3). As for Phase 1, energy balance closure of flux tower data for LUC Phases 2 to 4 (post-clearing phases) was high, with a slope $>0.9$ and $R^{2}>0.92$. Over all phases at the CS site, closure was lower, with a slope of $0.81\left(R^{2}=0.95, n=26395\right)$, similar to that of the UC site at $0.87\left(R^{2}=0.93, n=99998\right)$.

The 4-day clearing event occurred during relatively high soil moisture conditions, with surface $(5 \mathrm{~cm}$ depth) $\theta_{\mathrm{v}}$ ranging from 0.08 to $0.10 \mathrm{~m}^{3} \mathrm{~m}^{-3}$ and subsoil $\theta_{\mathrm{v}}$ $\left(50 \mathrm{~cm}\right.$ depth) ranging from 0.12 to $0.14 \mathrm{~m}^{3} \mathrm{~m}^{-3}$. As a result, pre-clearing fluxes were high and NEE reached
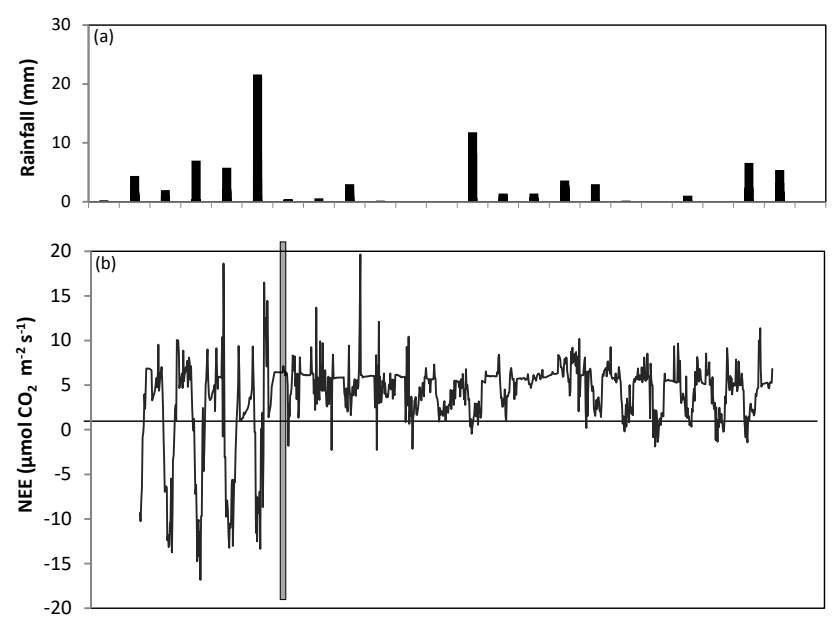

Figure 3. (a) Daily precipitation and (b) diurnal patterns of NEE at the CS site for the week prior to the clearing event of 26 March 2012 (vertical bar) and 3 weeks post-clearing.

$-15 \mu \mathrm{mol} \mathrm{CO} \mathrm{C}_{2} \mathrm{~m}^{-2} \mathrm{~s}^{-1}$ during the middle of the day (Fig. 3). Mean daily NEE for the week prior to clearing was a net $\mathrm{CO}_{2}$ sink of $-0.60 \pm 0.63 \mu \mathrm{mol} \mathrm{m}{ }^{-2} \mathrm{~s}^{-1}$ and was not significantly different to mean daily NEE at the UC site of $-0.80 \pm 0.93 \mu \mathrm{mol} \mathrm{m}^{-2} \mathrm{~s}^{-1}$ (ANOVA, $P<0.03$ ). For the 3 weeks following clearing, the CS site rapidly became a net source of $\mathrm{CO}_{2}$ with a mean daily NEE of $+4.38 \pm 0.24 \mu \mathrm{mol} \mathrm{m}^{-2} \mathrm{~s}^{-1}$, with a much reduced diurnal amplitude and no response to precipitation events (Fig. 3a, b). High closure (slope $>0.9$ ) was observed during Phases 2 to 4 , although this was reduced (slope $=0.75$ ) for the postfire and soil preparation, Phases 6-9.

Table 3 provides values of precipitation and monthly NEE, $R_{\mathrm{e}}$ and GPP for the seven LUC phases following clearing, namely debris decomposition and curing (153 days), burning (22 days), wet season regrowth ( 80 days), followed by soil tillage and preparation of irrigated raised soil beds (181 days). For each phase, the comparable flux estimate from the UC site is estimated for all post-clearing phases and for the entire observation period. Following clearing, GPP at the CS site was reduced by a factor of 3.5 when compared to the UC for the same period (March 2012-January 2013, Table 3). While greatly reduced, GPP still occurred at the CS site during this 13.7-month period $\left(-0.38 \mathrm{MgC} \mathrm{ha}^{-1}\right.$ month $\left.^{-1}\right)$ via resprouting of felled overstorey and subdominant trees and shrubs, as well as grass germination and growth stimulated by early wet season precipitation (November 2012-January 2013, $361 \mathrm{~mm}$, Table 3). Ecosystem respiration during this period was higher at the UC site $\left(+1.12 \mathrm{MgCha}^{-1}\right.$ month $\left.^{-1}\right)$ when compared to the CS site $\left(+0.82 \mathrm{MgCha}^{-1}\right.$ month $\left.^{-1}\right)$ and, given the large decline in GPP, the CS site was a small net $\mathrm{C}$ source at $+0.51 \mathrm{Mg} \mathrm{Cha}^{-1}$ month $^{-1}$, compared to the UC site which was a weak sink of $-0.03 \mathrm{MgCha}^{-1}$ month $^{-1}$. 


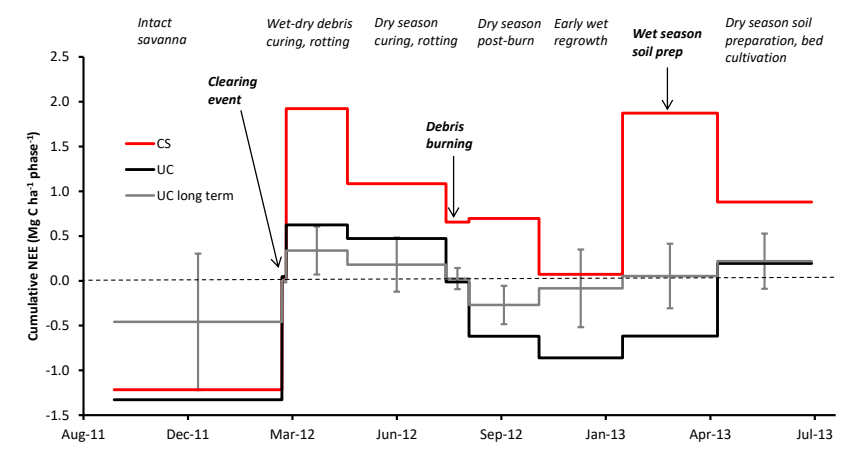

Figure 4. Cumulative NEE from the CS (red line) and UC sites (black line) for each land use phase (see Table 2 for details) over the entire observational period, September 2011 to July 2013. The UC site is a long-term savanna site of the Australian flux network (OzFlux, see Beringer et al., 2016a) and using the sites' 8-year flux record (2007-2013), the long-term cumulative mean NEE is plotted for each land use phase of (grey line; $\pm 95 \%$ CI). The dashed line indicates zero net $\mathrm{CO}_{2}$ flux.

Cumulative NEE over all the post-clearing LUC phases was $+7.2 \mathrm{MgCha}^{-1}$ at the CS site compared to a net sink of $-0.78 \mathrm{MgCha}^{-1}$ at the UC site (Table 3). The temporal dynamics of cumulative NEE across all LUC phases (note differences in phase duration) is summarised in Fig. 4, which compares fluxes from both sites for the complete observation period. Three significant periods of $\mathrm{C}$ emission are evident in Fig. 4. Firstly, the clearing event and the subsequent switch from a $\mathrm{C}$ sink to a net source of $1.9 \mathrm{MgCha}^{-1}$ due to soil disturbance and the decomposition of biomass. Secondly, this was followed by a reduction in source strength over the dry season of 2012, attributable to a reduction in $R_{\mathrm{e}}$ during the dry season (2012 dry season pre-burn phase, Table 3). Thirdly, there were other major emissions attributed to soil tillage and bed preparation in the wet and dry seasons of 2013, a cumulative net emission of $+2.75 \mathrm{MgC} \mathrm{ha}^{-1}$ that occurred over the final 6 months (Fig. 4) in preparation for cropping. Over this phase, the UC site was a net sink of $-0.62 \mathrm{Mg} \mathrm{Cha}^{-1}$.

\subsection{Emissions from debris burning}

Table 4 gives fuels loads, BEFs, EFs, carbon content and $\mathrm{N}: \mathrm{C}$ ratios for each fuel type used to estimate the GHG emission from the debris burning. Fuel load was dominated by heavy fuels with a mean $( \pm \mathrm{SD})$ above-ground biomass of $26.9 \pm 7.0 \mathrm{MgCha}^{-1}$ and a range of 14.4 to $39.3 \mathrm{MgCha}^{-1}$ across the eight biomass plots. The mean below-ground biomass was estimated at $9.0 \pm 2.4 \mathrm{MgC} \mathrm{ha}^{-1}$ and CWD was $1.4 \pm 0.6 \mathrm{Mg} \mathrm{Cha}^{-1}$. Fine and coarse fuels were $1.4 \pm 0.7$ and $0.5 \pm 1.0 \mathrm{MgCha}^{-1}$ respectively, giving a total fuel mass of $38.2 \mathrm{Mg} \mathrm{Cha}^{-1}$. Using these fuel loads with savanna EFs and the BEFs estimated for the site gave emissions of $\mathrm{CO}_{2}, \mathrm{CH}_{4}$ and $\mathrm{N}_{2} \mathrm{O}$ for each fuel type and the emission from debris burning totalled $121.9 \mathrm{Mg} \mathrm{CO}_{2}-\mathrm{e} \mathrm{ha}^{-1}$, with $9.5 \%$ of this total comprising non- $\mathrm{CO}_{2}$ emissions (Table 4).

\subsection{Total GHG emission}

Emissions derived from debris burning need to be combined with the post-clearing NEE as measured by the EC system to provide a total GHG emissions estimate from this LUC in units of $\mathrm{CO}_{2}$-e. The LUC phases following clearing spanned a 502-day period (Table 3), and NEE was $+7.2 \mathrm{MgCha}^{-1}$ or $+26.4 \mathrm{MgCO}_{2}$-eha ${ }^{-1}$. In comparison, NEE from the $\mathrm{UC}$ site over the same period was $-0.78 \mathrm{MgCha}^{-1}$ or $-2.9 \mathrm{CO}_{2}-\mathrm{eha}^{-1}$. Adding NEE from post-clearing phases (Phases 2-9, Table 3) to emissions from debris burning (Table 4) gave a total emission of $+148.3 \mathrm{Mg} \mathrm{CO}_{2}-\mathrm{e} \mathrm{ha}^{-1}$ for the $\mathrm{CS}$ site. The $\mathrm{CO}_{2}$-only emission from debris burning plus post-clearing NEE was $+136.7 \mathrm{MgCO}_{2} \mathrm{ha}^{-1}$, which was a flux 45 times larger than the observed savanna $\mathrm{CO}_{2}$ sink at the UC site over the post-clearing period.

\subsection{Upscaled and projected emissions from deforestation and savanna burning}

Table 5 provides mean $( \pm \mathrm{SD})$ GHG emissions estimates for savanna burning and deforestation for 1990-2013. At all spatial scales, annual mean burnt area dwarfed the mean annual land area deforested. For the Douglas-Daly catchment area, reported non- $\mathrm{CO}_{2}$ emissions from savanna burning were $577 \pm 124 \mathrm{Gg} \mathrm{CO}_{2}$-e $\mathrm{yr}^{-1}$, almost 4 times larger than emissions from the mean annual savanna deforestation rate of $163 \pm 162 \mathrm{GgCO}_{2}-\mathrm{e} \mathrm{yr}^{-1}$. For the Northern Territory savanna, mean annual burning emissions were an order of magnitude larger than mean annual deforestation emissions (Table 4) and 2 orders of magnitude larger if $\mathrm{CO}_{2}$ emissions were included. At a regional scale, the mean annual deforestation rate across the northern Australian savanna was $16161 \pm 5601 \mathrm{Gg} \mathrm{CO}_{2}$-e $\mathrm{yr}^{-1}$, with emissions from Queensland savanna area dominating this amount at $15762 \pm 5566 \mathrm{Gg} \mathrm{CO}_{2} \mathrm{yr}^{-1}$. This is double that of the reported (non- $\mathrm{CO}_{2}$ only) emission from prescribed burning at $6740 \pm 1740 \mathrm{Gg} \mathrm{CO}_{2}$-e $\mathrm{yr}^{-1}$ (Table 5).

Emissions estimates that include future deforestation rates would be equivalent to savanna burning, at least for the duration of the additional deforestation. For the Douglas-Daly catchment, this future emission is estimated at $756 \mathrm{Gg} \mathrm{CO}_{2}-$

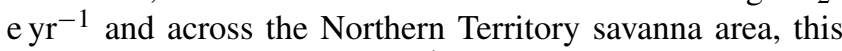
would be $3413 \mathrm{GgCO}_{2}$-e $\mathrm{yr}^{-1}$, rates of emission that are equivalent to burning emissions catchment (Douglas-Daly, $577 \pm 124$ ) and state scales (Northern Territory savanna, $3490 \pm 922 \mathrm{Gg} \mathrm{CO}_{2}-\mathrm{e} \mathrm{yr}^{-1}$ ). Emissions that include future deforestation rates for the northern Australian savanna region were estimated at $24393 \mathrm{Gg} \mathrm{CO}_{2}-\mathrm{e} \mathrm{yr}^{-1}$ and would be 3 times the reported savanna-burning annual emissions (Table 5). 
Table 4. Measured fuel loads, assumed burning efficiencies (BEFs), carbon contents, $\mathrm{N}: \mathrm{C}$ ratio and emissions factors (EFs) used to estimate GHG emissions from the burning of the post-deforestation fine, coarse and heavy fuel debris. Emission factors, carbon content and $\mathrm{C}$ : $\mathrm{N}$ ratio were assumed for the vegetation fuel type woodland savanna with mixed grass (code hWMi) as given in the Emissions Abatement through the Savanna Fire Management methodology (Commonwealth of Australia, 2015b), available at www.legislation.gov.au/Details/F2015L00344 and Meyers et al. (2012).

\begin{tabular}{|c|c|c|c|c|c|c|c|c|c|c|c|}
\hline \multirow[t]{2}{*}{ Fuel type } & \multirow{2}{*}{$\begin{array}{r}\text { Fuel load } \\
\left(\mathrm{MgCha}^{-1}\right)\end{array}$} & \multirow[t]{2}{*}{$\mathrm{BEF}$} & \multirow{2}{*}{$\begin{array}{l}\text { Carbon } \\
\text { content }\end{array}$} & \multirow{2}{*}{$\begin{array}{l}\mathrm{N}: \mathrm{C} \\
\text { ratio }\end{array}$} & \multirow[t]{2}{*}{$\mathrm{EF} \mathrm{CO} 2$} & \multirow[t]{2}{*}{$\mathrm{EF} \mathrm{CH}_{4}$} & \multirow[t]{2}{*}{$\mathrm{EF} \mathrm{N}_{2} \mathrm{O}$} & \multicolumn{4}{|c|}{ Emissions $\left(\mathrm{MgCO}_{2}\right.$-e ha $\left.{ }^{-1}\right)$} \\
\hline & & & & & & & & $\mathrm{CO}_{2}$ & $\mathrm{CH}_{4}$ & $\mathrm{~N}_{2} \mathrm{O}$ & Total \\
\hline Fine & $1.1 \pm 0.70$ & 0.95 & 0.46 & 0.0096 & 0.97 & 0.0031 & 0.0075 & 3.9 & 0.1 & 0.04 & 4.0 \\
\hline Coarse & $0.5 \pm 1.0$ & 0.9 & 0.46 & 0.0081 & 0.92 & 0.0031 & 0.0075 & 1.5 & 0.0 & 0.01 & 1.6 \\
\hline Heavy - AGB & $26.2 \pm 7.0$ & 0.9 & 0.46 & 0.0081 & 0.87 & 0.01 & 0.0036 & 75.2 & 7.9 & 0.32 & 83.4 \\
\hline Heavy - CWD & $1.4 \pm 0.6$ & 0.9 & 0.46 & 0.0081 & 0.87 & 0.01 & 0.0036 & 4.0 & 2.7 & 0.11 & 28.5 \\
\hline Heavy - BGB & $9.0 \pm 2.4$ & 0.9 & 0.46 & 0.0081 & 0.87 & 0.01 & 0.0036 & 25.7 & 0.0 & 0.02 & 4.4 \\
\hline Total & & & & & & & & 110.2 & 11.1 & 0.50 & 121.9 \\
\hline
\end{tabular}

\section{Discussion}

Australia has lost approximately $40 \%$ of its native forest and woodland since colonisation (Bradshaw, 2012), with most of this clearing for primary production in the eastern and south-eastern coastal region. Attention has now turned to the productivity potential of the largely intact northern savanna landscapes, which will involve trade-offs between management of land and water resources for primary production and biodiversity conservation (Adams and Pressey, 2014; Grundy et al., 2016). Globally and in Australia, savanna fire ecology and fire-derived GHG emissions have been reasonably well researched (Beringer et al., 1995; Cook and Meyer, 2009; Livesley et al., 2011; Meyer et al., 2012; Walsh et al., 2014; van der Werf et al., 2010) and the impacts of fire on the functional ecology of the Australian savanna has been recently reviewed by Beringer et al. (2015). In this study, we focussed on savanna deforestation and land preparation for agricultural use. These phases result in a series of events that may lead to pulsed GHG emissions that would otherwise be missed or greatly underestimated by episodic measurements taken at a weekly or monthly frequency after an initial treefelling event (Neill et al., 2006; Weitz et al., 1998).

We used the eddy covariance methodology as it provides a direct and non-destructive measurement of the net exchange of $\mathrm{CO}_{2}$ and other GHG gases at high temporal resolution, ranging from $30 \mathrm{~min}$ intervals to daily, monthly, seasonal and annual estimates. The method is useful as a full carbon accounting tool as all exchanges of $\mathrm{CO}_{2}$ from autotrophic and heterotrophic components of the ecosystem undergoing change are quantified (Hutley et al., 2005). This approach provides essential data for bottom-up GHG and carbon accounting studies as micrometeorological conditions and associated fluxes can be tracked through time for the duration of a land use conversion.

At the CS site, burning of post-clearing debris comprised $82 \%$ of the total emission of $148.4 \mathrm{MgCO}_{2}$-e ha ${ }^{-1}$, with the remainder attributed to NEE as measured by the flux tower. This flux comprised significant $\mathrm{CO}_{2}$ losses via respiration of debris, enhanced soil $\mathrm{CO}_{2}$ efflux from soil disturbance and tillage, which was partially offset by net uptake of $\mathrm{CO}_{2}$ from woody resprouting post-clearing and periods of grass growth following wet season rainfall (Fig. 4). Soil disturbance via ripping, tillage and preparation was responsible for $10 \%$ of the $\mathrm{CO}_{2}$ emission from the conversion. The $\mathrm{EC}$ flux tower was in operation during the clearing event, demonstrating the utility of this method as the switch of the ecosystem from being a net $\mathrm{CO}_{2}$ sink to being a net source. This occurred over a number of hours as the clearing event was completed (Fig. 3). During the LUC phase changes, there was little evidence of major pulses of $\mathrm{CO}_{2}$ flux, instead there was a rapid transition to a new diurnal pattern following the clearing (Fig. 3) or the commencement of soil preparation (data not shown). This is in contrast to non- $\mathrm{CO}_{2}$ flux emissions, in particular $\mathrm{N}_{2} \mathrm{O}$, with short-term emissions often following disturbances (Grover et al., 2012; Zona et al., 2013) and can account for a significant fraction of annual emissions.

The net $\mathrm{CO}_{2}$ source measured by the flux tower represents an emission that would be missed if vegetation biomass density alone was used to estimate LUC emissions, which is the approach currently used in remote sensing LUC studies at regional and continental scales. The total GHG emission we report in this study is more accurately described as a land conversion, as it includes the oxidation of biomass plus emissions associated with soil disturbance and tillage required for a conversion to a cropping or grazing system.

The emission estimate from this study does not include non- $\mathrm{CO}_{2}$ soil-derived fluxes of $\mathrm{CH}_{4}$ and $\mathrm{N}_{2} \mathrm{O}$, which can be significant for LUC events in certain ecosystems (Tian et al., 2015). Grover et al. (2012) compared soil $\mathrm{CO}_{2}$ and non- $\mathrm{CO}_{2}$ fluxes from native savanna with young pasture and old pastures (5-7 and 25-30 years old) in the Douglas-Daly river catchment. Soil emissions of $\mathrm{CO}_{2}$-e were $30 \%$ greater on the pasture sites compared with native savanna sites, with this change being dominated by increases in $\mathrm{CO}_{2}$ emission and soil $\mathrm{CH}_{4}$ exchange shifting from a small net sink to a small net source at the pasture sites. Non- $\mathrm{CO}_{2}$ soil fluxes were generally small, especially $\mathrm{N}_{2} \mathrm{O}$ emissions, although these mea- 


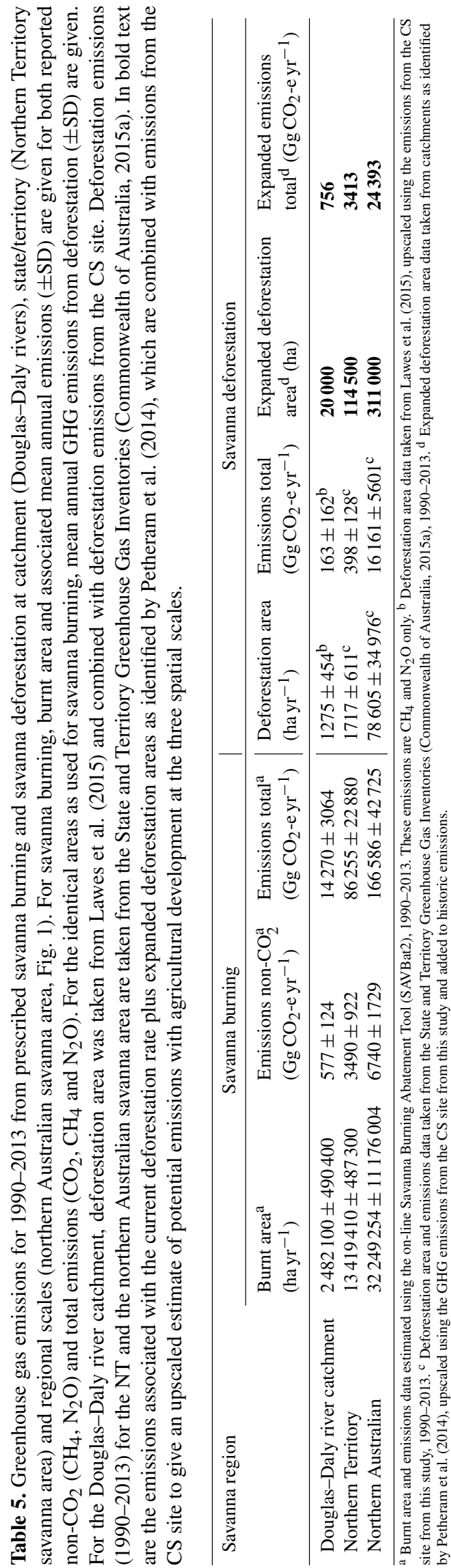

surements were made many years after the LUC event and there is uncertainty as to their relevance for a recently deforested and converted savanna site. An additional pathway for $\mathrm{CH}_{4}$ and $\mathrm{N}_{2} \mathrm{O}$ emissions in these savannas is via termite activity (Jamali et al., 2011a, b). In our study, termite mounds were abundant across the CS site but were largely destroyed by clearing and soil preparation, potentially reducing the net non- $\mathrm{CO}_{2}$ emission following conversion. Further work is required to quantify these non- $\mathrm{CO}_{2}$ fluxes not associated with debris burning to refine our total emission estimate for savanna deforestation.

This land conversion represents the loss of decades of carbon accumulation in these mesic savanna ( $>1000 \mathrm{~mm}$ MAP), ecosystems which are currently thought to be a weak carbon sink (Beringer et al., 2015). The 8-year ensemble mean NEE for the UC site was $-0.11 \pm 0.16 \mathrm{MgCha}^{-1} \mathrm{yr}^{-1}$ and is representative of a savanna site at a near-equilibrium state in terms of carbon balance given the low fire frequency (3 in 13 years, Table 1) with high severity fires uncommon (1 in 8 years of flux measurements). The annual increase in tree biomass at this $\mathrm{UC}$ site is $0.6 \mathrm{tC} \mathrm{ha}^{-1} \mathrm{yr}^{-1}$ (Rudge, Hutley, Beringer, unpublished data) and, given an above-ground standing biomass of $28 \mathrm{tC} \mathrm{ha}^{-1}$, suggests a regeneration period of approximately four to five decades after stand replacement disturbance event such as deforestation for this savanna type.

Even after the large pool of carbon is lost following oxidation of biomass, carbon loss may continue on cleared land via continued soil carbon mineralisation, leading to a slow decline in soil carbon storage that is frequently reported for forest to cropping LUC (Jarecki and Lal, 2003; Lal and Follett, 2009). Conversion of forest or woodland to improved pasture grazing may result in either increases or decreases in soil carbon (Sanderman et al., 2010). Alternatively, it is possible that carbon sequestration may occur post-clearing via woody regrowth if a cleared site is abandoned and not further prepared for cultivation. This has actually been a relatively common transition and a significant sequestration pathway that needs to be included in savanna LUC assessments (Henry et al., 2015). Admittedly, if savanna-cleared land does fully transition to a cropping system, some fraction of the lost carbon could also be replaced or sequestered by new horticultural or forestry land uses.

There are few detailed, plot-scale studies of GHG emissions from savanna clearing in northern Australia. Several studies (Law and Garnett, 2009, 2011) used the Full Carbon Accounting Model (FullCAM Ver 3.0, Commonwealth of Australia, 2015a; Richards and Evans, 2004) to generate spatial maps of above- and below-ground biomass and soil organic carbon pools across the NT. The FullCAM model uses spatial and temporal soil, climate, precipitation data with NVIS major vegetation classes to simulate carbon losses (as GHG emissions) and uptake between the terrestrial biological system and the atmosphere. Land use change scenarios can be run within the model and Law and Gar- 
nett (2009) examined deforestation emissions from the Eucalypt woodland NVIS vegetation class, as per UC and CS site classification. Modelled emissions were $136 \pm 42 \mathrm{Mg} \mathrm{CO}_{2}$-e, comparable to our deforestation estimate of $121.4 \mathrm{Mg} \mathrm{CO}_{2}$ e. Henry et al. (2015) used a life cycle assessment approach to quantify GHG emissions from LUC associated with beef production in eastern Australia. Australia's major beef-producing areas across central and southern Queensland and northern central New South Wales were classified into 11 bioregions, with the northernmost bioregion, the northern Brigalow Belt, falling within the savanna biome. Vegetation biomass from this bioregion was estimated at $84.7 \pm 7.1 \mathrm{Mg} \mathrm{ha}^{-1}$ or $\sim 41.4 \mathrm{MgCha}^{-1}$, with an emission estimated at $129 \mathrm{Mg} \mathrm{CO}_{2}$-e (Henry et al., 2015), similar to the woodland biomass density and resultant emission with deforestation from the CS site of this study.

Our emissions estimate is robust for this vegetation class and can be upscaled and compared with other land sector activities such as prescribed savanna burning. At a regional scale, current levels of savanna burning dominate emissions compared to land clearing rates (Table 5). The cumulative deforestation area across the savanna region since 1990 ( $1886512 \mathrm{ha})$ is 17 times smaller than the mean annual savanna burn area (32 Mha, Table 5), as approximately 30 to $70 \%$ of the savanna area is burnt annually (Russell-Smith et al., 2009a). Modelling NEP for savanna biome for 19902010 (Beringer et al., 2015; Haverd et al., 2013) suggests the northern Australian savanna is near carbon neutrality or is a weak source of $\mathrm{CO}_{2}$ to the atmosphere once regionalscale fire emissions are included. As such, the IPCC assumption that $\mathrm{CO}_{2}$ emissions from the previous year's burning are recovered by the following year's wet season growth may have some validity for regional-scale GHG accounting. This assumption at plot-to-catchment scales may not be valid, as localised interannual variability in rainfall, site history and fire management can result in either net accumulation or loss of carbon (Hutley and Beringer, 2011; Murphy et al., 2014, 2015b). Assuming year-to-year $\mathrm{CO}_{2}$ emitted from burning is resequestered, assessment of the non- $\mathrm{CO}_{2}$ only emissions from savanna burning with deforestation is useful. This comparison suggests projected deforestation emissions (24393 $\mathrm{Gg} \mathrm{CO}_{2}$-e $\mathrm{yr}^{-1}$, Table 5) could be well in excess of current annual burning emissions $\left(6740 \mathrm{Gg} \mathrm{CO}_{2}\right.$-e $\mathrm{yr}^{-1}$, Table 5), at least for the period of enhanced clearing, which in this study we assumed to be 5 years.

In 2013, Australia's total reported GHG emission was $548440 \mathrm{Gg} \mathrm{CO}_{2}$-e and the impact of expanded savanna deforestation on the national emission can be estimated using data in Table 5, which provide estimates of mean annual emissions from the deforestation area, giving a mean annual deforestation emission per ha averaged for the entire savanna area, which is $221 \pm 50.8 \mathrm{Mg} \mathrm{CO}_{2}$-e ha ${ }^{-1}$ using 1990 to 2013 data (Commonwealth of Australia, 2015a). This value represents a spatially averaged emission as it is derived from the full range of savanna vegetation types and above-ground biomass, which across the Northern Territory savanna area ranges from 10 to $70 \mathrm{Mg} \mathrm{Cha}^{-1}$ (Law and Garnett, 2011). Assuming this emission per ha, an additional 311000 ha of savanna deforestation, cleared over a 5-year period, adds $12099 \mathrm{Gg} \mathrm{CO}_{2}$-e $\mathrm{yr}^{-1}$. For the duration of the expanded deforestation, this is a $2.2 \%$ increase to Australia's nation emission over and above the historic savanna LUC emissions $\left(16161 \mathrm{Gg} \mathrm{CO}_{2}-\mathrm{e} \mathrm{yr}^{-1}\right.$ ), which are $2.9 \%$ of national emissions. Using our finding from flux tower measurements that a land conversion (deforestation followed by site tillage and preparation for cultivation) adds an additional $18 \%$ of GHG emissions to a deforestation event, expansion of northern land development could add an additional $3 \%$ or $33350 \mathrm{Gg} \mathrm{CO}_{2}$-e $\mathrm{yr}^{-1}$ to the reportable national GHG emissions for the duration of the expanded deforestation period.

This assessment is subject to a number of uncertainties. Firstly, a component of our emissions estimate is based on eddy covariance measurements of $\mathrm{CO}_{2}$ flux, which typically have an error of 10-20\% (Aubinet et al., 2012). In this study, energy balance closure suggested fluxes were underestimated by up to $13 \%$ across the entire observation period. Energy balance closure ranged from $<10 \%$ flux loss during the intact canopy phase to $>20 \%$ error during the final three LUC phases when the flux instruments were at $3 \mathrm{~m}$ height measuring net soil $\mathrm{CO}_{2}$ emissions from the smoothed, vegetation-free ploughed soil surface during preparation. Secondly, it is difficult to predict the nature of future deforestation (rate, area, specific location) and the emission comparisons presented here are indicative only. Catchments selected by Petheram et al. (2014) regarded as suitable or with potential for future development were based on biophysical properties only, were unconstrained by the regulatory environment and did not account for conservation and cultural values placed on identified land and water resources. In addition, challenges to agricultural expansion in northern Australia include uncertain land and water tenure, high development costs and lack of existing water infrastructure, logistics and technical constraints, lack of human capital and distance to markets, all factors that may restrict land clearing. It is well understood that the availability and cost of water for irrigated, or irrigation-assisted agriculture is critical for viable agriculture in northern Australia (Petheram et al., 2008, 2009). Australian governmental policies currently support small-scale, precinct or project-scale approaches, based on well-understood water and soil resources, where water allocation is capped. The current policy and market instruments are likely to ensure that development remains measured and restricted, unlike development of previous decades in other regions of eastern and southern Australia.

As a result we used a conservative estimate of potential land suitability area $(311000$ ha over a 5-year clearing period), as estimates of assumed clearable area ranging up to 700000 ha (e.g. Douglas-Daly catchment, Adams and Pressey, 2014) or over 1 million ha across northern Australia (Petheram et al., 2014), areas that may be unlikely 
given capital investment requirements as well as conservation and cultural considerations. Our comparison with burning emissions is also influenced by the deforestation period we assume. This was based on patterns of historic rates of clearing as there are periods when deforestation rates have easily exceeded 311000 ha over 5-year periods, particularly in Queensland (Commonwealth of Australia, 2015a) and a longer duration of deforestation reduces the impact on annual national GHG accounting.

There is also uncertainty arising from our emissions from debris burning. Russell-Smith et al. (2009b) estimated errors associated with emissions estimates from the Western Arnhem Land Fire Abatement (WALFA) project, a savanna burning based GHG abatement scheme operating in the Northern Territory. This is a project area of the $23893 \mathrm{~km}^{2}$ consisting of a wide range of vegetation types including open-forest and woodland savanna and sandstone heaths in escarpment areas. Russell-Smith et al. (2009b) estimated the accountable emissions from savanna burning at $272 \pm 100 \mathrm{Gg} \mathrm{CO}_{2}$ -

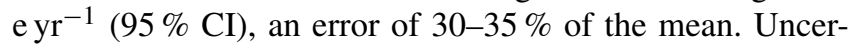
tainty was ascribed to errors in remotely sensed burn area mapping, fuel load estimation, spatial variation of fire severity, errors in BEF for each fuel class and EFs. At the spatial scale of our study area, there were no uncertainties with the burnt area, vegetation structure or fuel type classification, and we used site-specific fuel load estimations used in our calculations, all of which would reduce the error associated with our fire emissions estimate. Russell-Smith et al. (2009b) also reported low coefficients of variability (CV\%) of for BEFs across fine, course and heavy fuel types for high severity fires, ranging from 0.3 to $11 \%$ and $2 \% \mathrm{CV}$ for $\mathrm{EFs}$ for $\mathrm{CH}_{4}$ and $\mathrm{N}_{2} \mathrm{O}$. Site-specific sources of error include high spatial variability of on-site fuel loads which had a CV \% of $\sim 70 \%$ (Table 4 ) and uncertainty associated with the BEF we assumed for coarse and heavy fuel loads (0.9), which is higher than that derived for late dry season savanna fires (0.36, 0.31 respectively, Russell-Smith et al., 2009b). This value was assumed as repeat burning of coarse and heavy fuels ensured $\sim 10 \%$ of biomass remained as ash and charcoal at the CS site. This assumed BEF is also consistent with FullCAM (4.00.3) BEF of 0.98 for forest fire with $100 \%$ of trees killed, although this is setting is based on Surawski et al. (2012) who found little empirical evidence for BEF for stand replacement fires. However, given the detailed on-site measurements of fuel load, error in our fire-derived emissions would be of the order of $20 \%$ or less.

\section{Conclusions}

While GHG emissions from savanna deforestation are dominated by debris burning, emissions from soil tillage and soil bed preparation are likely to be $20 \%$ of the total emission, suggesting that satellite-based emissions based on oxidation of cleared vegetation alone do not capture all phases of LUC prior to cultivation. Savanna burning, using the area as defined in this study, was $1.5 \%$ of Australia's national GHG emissions and is of similar magnitude to emissions associated with historic savanna deforestation. However, the deforestation scenario could increase Australia's GHG emissions by at least $3 \%$ per annum for the duration of the expansion, depending on the area and deforestation rate. These are indicative estimates only, but suggest that the impacts of northern agricultural development will have an impact on the national GHG budget and will need to be considered in northern land use decision making processes. These considerations are also particularly relevant given the emission reduction targets set by Australia following the 21st Conference of Parties to the UN Framework Convention on Climate Change (COP21/CMP11) to reduce GHG emissions by 26 to $28 \%$ from 2005 to 2030.

\section{Data availability}

Flux data from the UC and CS tower sites is available from Australia's Terrestrial Ecosystem Research Network (TERN, http://tern.org.au/) OzFlux Data Portal. Data can be accessed from http://data.ozflux.org.au/portal/site/datainfo.jspx under a user licence as described at http://data.ozflux.org.au/portal/ site/licenceinfo.jspx. Fire-derived GHG emissions data can be estimated via the SavBat2 online calculation tool as described in the text using emissions factors and burning efficacies as given in Table 4. Deforestation data are available via the technical reports as cited, with savanna-specific data available on request to the corresponding author.

Acknowledgements. Financial support for this study was provided by the Australian Research Council's Linkage Project LP100100073 and Discovery Project DP0772981. Jason Beringer is funded under the Australian Research Council's Future Fellowship program (FT1110602). Support for flux data collection and archiving was provided by Peter Isaac of the Australian flux network, OzFlux (www.ozflux.org.au), which is funded by the Australian Terrestrial Ecosystem Research Network (TERN, www.tern.org.au). Chris and Bridget Schulz provided access to the property and field assistance throughout all phases of the land use change we monitored. We are grateful for the technical expertise and field assistance of Matthew Northwood and Michael Brand who maintained the eddy covariance tower. Yan-Shih Lin, Amanda Lilleyman and Allison O'Keefe provided field support during the intensive field campaigns. Thanks also to the Department of Environment for provision of savanna-specific deforestation GHG emissions data, 1990-2013 and the two reviewers who provided constructive comments on the original manuscript.

Edited by: B. Amiro

Reviewed by: B. Amiro and one anonymous referee 


\section{References}

Adams, V. M. and Pressey, R. L.: Uncertainties around the Implementation of a Clearing-Control Policy in a unique catchment in Northern Australia: exploring equity issues and balancing competing objectives, PLoS One, 9, e9647, doi:10.1371/journal.pone.0096479, 2014.

Aldrick, J. M. and Robinson, C. S.: Report on the Land Units of the Katherine-Douglas Area, Northern Territory Service, Land Conservation Section of the Northern Territory Administration, Department of the Interior, Canberra, 1972.

Anthoni, P. M., Knohl, A., Rebmann, C., Freibauer, A., Mund, M., Ziegler, W., Kolle, O., and Schulze, E.-D.: Forest and agricultural land-use-dependent $\mathrm{CO}_{2}$ exchange in Thuringia, Germany, Glob. Change Biol., 10, 2005-2019, doi:10.1111/j.13652486.2004.00863.x, 2004.

Aubinet, M., Vesala, T., and Papale, D.: Eddy Covariance: A Practical Guide to Measurement and Data Analysis, Springer, Dordrecht, 2012.

Baccini, A., Goetz, S. J., Walker, W. S., Laporte, N. T., Sun, M., Sulla-Menashe, D., Hackler, J., Beck, P. S. A., Dubayah, R., Friedl, M. A., Samanta, S., and Houghton, R. A.: Estimated carbon dioxide emissions from tropical deforestation improved by carbon-density maps, Nature Climate Change, 2, 182-185, 2012.

Beringer, J., Packham, D., and Tapper, N.: Biomass burning and resulting emissions in the northern territory, Australia, Int. J. Wildland Fire, 5, 229-235, doi:10.1071/WF9950229, 1995.

Beringer, J., Hutley, L. B., Tapper, N. J., and Cernusak, L. A.: Savanna fires and their impact on net ecosystem productivity in North Australia, Glob. Change Biol., 13, 990-1004, doi:10.1111/j.1365-2486.2007.01334.x, 2007.

Beringer, J., Hacker, J., Hutley, L. B., Leuning, R., Arndt, S. K., Amiri, R., Bannehr, L., Cernusak, L. A., Grover, S., Hensley, C., Hocking, D., Isaac, P., Jamali, H., Kanniah, K., Livesley, S., Neininger, B., Paw, U. K. T., Sea, W., Straten, D., Tapper, N., Weinmann, R., Wood, S., and Zegelin, S.: Special-Savanna patterns of energy and carbon integrated across the landscape, B. Am. Meteorol. Soc., 92, 1467-1485, doi:10.1175/2011bams2948.1, 2011.

Beringer, J., Hutley, L. B., Abramson, D., Arndt, S. K., Briggs, P., Bristow, M., Canadell, J. G., Cernusak, L. A., Eamus, D., Edwards, A. C., Evans, B. J., Fest, B., Goergen, K., Grover, S. P., Hacker, J., Haverd, V., Kanniah, K., Livesley, S. J., Lynch, A., Maier, S., Moore, C., Raupach, M., Russell-Smith, J., Scheiter, S., Tapper, N. J., and Uotila, P.: Fire in Australian savannas: from leaf to landscape., Glob. Change Biol., 21, 62-81, doi:10.1111/gcb.12686, 2015.

Beringer, J., Hutley, L. B., McHugh, I., Arndt, S. K., Campbell, D., Cleugh, H. A., Cleverly, J., Resco de Dios, V., Eamus, D., Evans, B., Ewenz, C., Grace, P., Griebel, A., Haverd, V., Hinko-Najera, N., Huete, A., Isaac, P., Kanniah, K., Leuning, R., Liddell, M. J., Macfarlane, C., Meyer, W., Moore, C., Pendall, E., Phillips, A., Phillips, R. L., Prober, S., Restrepo-Coupe, N., Rutledge, S., Schroder, I., Silberstein, R., Southall, P., Sun, M., Tapper, N. J., van Gorsel, E., Vote, C., Walker, J., and Wardlaw, T.: An introduction to the Australian and New Zealand flux tower network OzFlux, Biogeosciences Discuss., doi:10.5194/bg-2016-152, in review, 2016a.

Beringer, J., McHugh, I., Hutley, L. B., Isaac, P., and Kljun, N.: Dynamic INtegrated Gap-filling and partitioning for OzFlux
(DINGO), Biogeosciences Discuss., doi:10.5194/bg-2016-188, in review, 2016b.

Bradshaw, C. J. A.: Little left to lose: deforestation and forest degradation in Australia since European colonization, J. Plant Ecol., 5, 109-120, doi:10.1093/jpe/rtr038, 2012.

Brown, S.: Estimating biomass and biomass change of tropical forest: a primer, FAO Forestry Paper 134, Rome, www.fao. org/docrep/w4095e/w4095e00.htm (last access: 20 April 2016), 1997.

Committee on Northern Australia: PIVOT NORTH Inquiry into the Development of Northern Australia: Final Report, Commonwealth of Australia, Canberra, 2014.

Commonwealth of Australia: Australian Vegetation Attribute Manual: National Vegetation Information System, Version 6.0, Canberra, 2003.

Commonwealth of Australia: State and Territory Greenhouse Gas Inventories 2013, Canberra, 2015a.

Commonwealth of Australia: Carbon Credits (Carbon Farming Initiative-Emissions Abatement through Savanna Fire Management) Methodology Determination, www.legislation.gov.au/ Details/F2015L00344 (last access: 8 July 2016), Department of the Environment, Canberra, 2015b.

Cook, G. D.: Historical perspectives on land use development in northern Australia, in Northern Australia Land and Water Science Review, Office of North Australia, Commonwealth of Australia, Canberra, 2009.

Cook, G. D. and Meyer, C. P.: Fire, fuels and greenhouse gases, in Culture, Ecology, and Economy of Fire Management in North Australian Savannas: Rekindling the Wurrk Tradition, edited by: Russell-Smith, J., Whitehead, P., and Cooke, P., CSIRO Publishing, Melbourne, 313-328, 2009.

Eamus, D., Chen, X., Kelley, G., and Hutley, L. B.: Root biomass and root fractal analyses of an open Eucalyptus forest in a savanna of north Australia, Aust. J. Bot., 50, 31-41, doi:10.1071/bt01054, 2002.

Fearnside, P. M., Righi, C. A., Graça, P. M. L. de A., Keizer, E. W. H., Cerri, C. C., Nogueira, E. M., and Barbosa, R. I.: Biomass and greenhouse-gas emissions from land-use change in Brazil's Amazonian "arc of deforestation": The states of Mato Grosso and Rondônia, Forest Ecol. Manag., 258, 1968-1978, doi:10.1016/j.foreco.2009.07.042, 2009.

Ferreira, M. E., Ferreira, L. G., Miziara, F., and SoaresFilho, B. S.: Modeling landscape dynamics in the central Brazilian savanna biome: future scenarios and perspectives for conservation, J. Land Use Sci., 8, 403-421, doi:10.1080/1747423X.2012.675363, 2013.

Ferreira, M. E., Ferreira, L. G., Latrubesse, E. M., and Miziara, F.: Considerations about the land use and conversion trends in the savanna environments of Central Brazil under a geomorphological perspective, J. Land Use Sci., 11, 33-47, 2016.

Fisher, R. and Edwards, A. C.: Fire extent and mapping: procedures, validation and website application, in Carbon Accounting and Savanna Fire Management, edited by: Murphy, B. P., Edwards, A. C., Meyer, C. P., and Russell-Smith, J., CSIRO Publishing, Melbourne, Australia, 57-72, 2015.

Fox, I. D., Neldner, V. J., Wilson, G. W., and Bannink, P. J.: The Vegetation of the Australian Tropical Savannas, Brisbane, 2001.

Galford, G. L., Melillo, J. M., Kicklighter, D. W., Mustard, J. F., Cronin, T. W., Cerri, C. E. P., and Cerri, C. C.: Historical carbon 
emissions and uptake from the agricultural frontier of the Brazilian Amazon, Ecol. Appl., 21, 750-763, doi:10.1890/09-1957.1, 2011.

Galford, G. L., Soares-Filho, B., and Cerri, C. E. P.: Prospects for land-use sustainability on the agricultural frontier of the Brazilian Amazon, Philos. T. R. Soc. Lon. B, 368, 20120171, doi:10.1098/rstb.2012.0171, 2013.

Grace, J., San, J. J., Meir, P., Miranda, H. S., Montes, R. A., José, J. S., Meir, P., Miranda, H. S., and Montes, R. A.: Productivity and carbon fluxes of tropical savannas, J. Biogeogr., 33, 387-400, doi:10.1111/j.1365-2699.2005.01448.x, 2006.

Grover, S. P. P., Livesley, S. J., Hutley, L. B., Jamali, H., Fest, B., Beringer, J., Butterbach-Bahl, K., and Arndt, S. K.: Land use change and the impact on greenhouse gas exchange in north Australian savanna soils, Biogeosciences, 9, 423-437, doi:10.5194/bg-9-423-2012, 2012.

Grundy, M. J., Bryan, B. A., Nolan, M., Battaglia, M., HatfieldDodds, S., Connor, J. D., and Keating, B. A.: Scenarios for Australian agricultural production and land use to 2050, Agric. Syst., 142, 70-83, doi:10.1016/j.agsy.2015.11.008, 2016.

Haverd, V., Raupach, M. R., Briggs, P. R., J. G. Canadell., Davis, S. J., Law, R. M., Meyer, C. P., Peters, G. P., Pickett-Heaps, C., and Sherman, B.: The Australian terrestrial carbon budget, Biogeosciences, 10, 851-869, doi:10.5194/bg-10-851-2013, 2013.

Henry, B. K., Butler, D., and Wiedemann, S. G.: A life cycle assessment approach to quantifying greenhouse gas emissions from land-use change for beef production in eastern Australia, Rangel. J., 37, 273-283, doi:10.1071/RJ14112, 2015.

Houghton, R. A., House, J. I., Pongratz, J., van der Werf, G. R., DeFries, R. S., Hansen, M. C., Le Quéré, C., and Ramankutty, N.: Carbon emissions from land use and land-cover change, Biogeosciences, 9, 5125-5142, doi:10.5194/bg-9-5125-2012, 2012.

Hutley, L. B. and Beringer, J.: Disturbance and climatic drivers of carbon dynamics of a north Australian tropical savanna, in Ecosystem Function in Savannas: Measurement and Modeling at Landscape to Global, edited by: Hill, M. J. and Hanan, N. P., CRC Press, Boca Raton, 2011.

Hutley, L. B., Leuning, R., Beringer, J., and Cleugh, H. A.: The utility of the eddy covariance techniques as a tool in carbon accounting: tropical savanna as a case study, Aust. J. Bot., 53, 663-675, doi:10.1071/bt04147, 2005 .

Hutley, L. B., Beringer, J., Isaac, P. R., Hacker, J. M., and Cernusak, L. A.: A sub-continental scale living laboratory: Spatial patterns of savanna vegetation over a precipitation gradient in northern Australia, Agr. Forest Meteorol., 151, 1417-1428, doi:10.1016/j.agrformet.2011.03.002, 2011.

IPCC: Revised 1996 Intergovernmental Panel on Climate Change (IPCC) Guidelines for National Greenhouse Gas Inventories 3 vols, IPCC/OECD/IEA: Paris, France, 1997.

IPCC: Good Practice Guidance for Land Use, Land-Use Change and Forestry, edited by: Penman, J., Gytarsky, M., Hiraishi, T., Krug, T., Kruger, D., Pipatti, R., Buendia, L., Miwa, K., Ngara, T., Tanabe, K., and Wagner, F., Institute for Global Environmental Strategies for the Intergovernmental Panel on Climate Change, Kanagawa, Japan, 2003.

IPCC: Climate Change 2013: The Physical Science Basis. Contribution of Working Group I to the Fifth Assessment Report of the Intergovernmental Panel on Climate Change, edited by: Stocker, T. F., Qin, D., Plattner, G.-K., Tignor, M., Allen, S. K., Boschung,
J., Nauels, A., Xia, Y., Bex, V., and Midgley, P. M., Cambridge University Press, Cambridge, United Kingdom, 2013.

Isaac, P., Cleverly, J., McHugh, I., van Gorsel, E., Ewenz, C., and Beringer, J.: OzFlux Data: Network integration from collection to curation, Biogeosciences Discuss., doi:10.5194/bg-2016-189, in review, 2016.

Isbell, R.: The Australian Soil Classification, in: Australian Soil and Land Survey Handbook, CSIRO Publishing, Melbourne, 2002.

Jamali, H., Livesley, S. J., Dawes, T. Z., Hutley, L. B., and Arndt, S. K.: Termite mound emissions of $\mathrm{CH}_{4}$ and $\mathrm{CO}_{2}$ are primarily determined by seasonal changes in termite biomass and behaviour, Oecologia, 167, 525-534, doi:10.1007/s00442-0111991-3, 2011a.

Jamali, H., Livesley, S. J., Grover, S. P., Dawes, T. Z., Hutley, L. B., Cook, G. D., and Arndt, S. K.: The Importance of Termites to the CH4 Balance of a Tropical Savanna Woodland of Northern Australia, Ecosystems, 14, 698-709, doi:10.1007/s10021-011-9439$5,2011 b$.

Jarecki, M. K. and Lal, R.: Crop Management for Soil Carbon Sequestration, Cr. Rev. Plant Sci., 22, 471-502, doi:10.1080/713608318, 2003.

Jones, D., Wang, W., and Fawcett, R.: High-quality spatial climate data sets for Australia, Aust. Meteorol. Oceanogr. J., 58, 233248, 2009.

Lal, R. and Follett, R. F.: Soils and climate change, in Soil Carbon Sequestration and the Greenhouse Effect, edited by: Lal, R. and Follett, R. F., Soil Science Society of America, Maddison, 1-23, 2009.

Lambin, E. F., Gibbs, H. K., Ferreira, L., Grau, R., Mayaux, P., Meyfroidt, P., Morton, D. C., Rudel, T. K., Gasparri, I., and Munger, J.: Estimating the world's potentially available cropland using a bottom-up approach, Global Environ. Chang., 23, 892901, doi:10.1016/j.gloenvcha.2013.05.005, 2013.

Landsberg, J., Gillieson, D., and Salt, D.: Trees in savanna landscapes: finding the balance, David Gillison, Cooperative Research Centre for Tropical Savannas Management, Charles Darwin University, Darwin, Australia, 2011.

Lapola, D. M., Martinelli, L. A., Peres, C. A., Ometto, J. P. H. B., Ferreira, M. E., Nobre, C. A., Aguiar, A. P. D., Bustamante, M. M. C., Cardoso, M. F., Costa, M. H., Joly, C. A., Leite, C. C., Moutinho, P., Sampaio, G., Strassburg, B. B. N., and Vieira, I. C. G.: Pervasive transition of the Brazilian land-use system, Nature Climate Change, 4, 27-35, doi:10.1038/nclimate2056, 2014.

Law, R. and Garnett, S. T.: Understanding carbon in the Northern Territory: an analysis of future land use scenarios using the national carbon accounting tool, Cooperative Research Centre for Tropical Savannas Management, Darwin, 2009.

Law, R. and Garnett, S. T.: Mapping carbon in tropical Australia: Estimates of carbon stocks and fluxes in the Northern Territory using the national carbon accounting toolbox, Ecol. Manag. Restor., 12, 61-68, doi:10.1111/j.14428903.2011.00566.x, 2011.

Lawes, M. J., Greiner, R., Leiper, I. A., Ninnis, R., Pearson, D., and Boggs, G.: The effects of a moratorium on land-clearing in the Douglas-Daly region, Northern Territory, Australia, Rangel. J., 37, 399-408, doi:10.1071/RJ15014, 2015.

Le Quéré, C., Moriarty, R., Andrew, R. M., Peters, G. P., Ciais, P., Friedlingstein, P., Jones, S. D., Sitch, S., Tans, P., Arneth, A., Boden, T. A., Bopp, L., Bozec, Y., Canadell, J. G., Chini, L. P., 
Chevallier, F., Cosca, C. E., Harris, I., Hoppema, M., Houghton, R. A., House, J. I., Jain, A. K., Johannessen, T., Kato, E., Keeling, R. F., Kitidis, V., Klein Goldewijk, K., Koven, C., Landa, C. S., Landschützer, P., Lenton, A., Lima, I. D., Marland, G., Mathis, J. T., Metzl, N., Nojiri, Y., Olsen, A., Ono, T., Peng, S., Peters, W., Pfeil, B., Poulter, B., Raupach, M. R., Regnier, P., Rödenbeck, C., Saito, S., Salisbury, J. E., Schuster, U., Schwinger, J., Séférian, R., Segschneider, J., Steinhoff, T., Stocker, B. D., Sutton, A. J., Takahashi, T., Tilbrook, B., van der Werf, G. R., Viovy, N., Wang, Y.-P., Wanninkhof, R., Wiltshire, A., and Zeng, N.: Global carbon budget 2014, Earth Syst. Sci. Data, 7, 47-85, doi:10.5194/essd-7-47-2015, 2015.

Livesley, S. J., Grover, S., Hutley, L. B., Jamali, H., ButterbachBahl, K., Fest, B., Beringer, J., and Arndt, S. K.: Seasonal variation and fire effects on $\mathrm{CH}_{4}, \mathrm{~N}_{2} \mathrm{O}$ and $\mathrm{CO}_{2}$ exchange in savanna soils of northern Australia, Agr. Forest Meteorol., 151, 14401452, doi:10.1016/j.agrformet.2011.02.001, 2011.

Macfarlane, C., Hoffman, M., Eamus, D., Kerp, N., Higginson, S., McMurtrie, R., and Adams, M.: Estimation of leaf area index in eucalypt forest using digital photography, Agr. Forest Meteorol., 143, 176-188, doi:10.1016/j.agrformet.2006.10.013, 2007.

Mayocchi, C. L. and Bristow, K. L.: Soil surface heat flux: some general questions and comments on measurements, Agr. Forest Meteorol., 75, 43-50, 1995.

Meyer, C. P., Cook, G. D., Reisen, F., Smith, T. E. L., Tattaris, M., Russell-Smith, J., Maier, S. W., Yates, C. P., and Wooster, M. J.: Direct measurements of the seasonality of emission factors from savanna fires in northern Australia, J. Geophys. Res.Atmos., 117, 2156-2202, doi:10.1029/2012JD017671, 2012.

Murphy, B. P., Lehmann, C. E. R., Russell-Smith, J., and Lawes, M. J.: Fire regimes and woody biomass dynamics in Australian savannas, J. Biogeogr., 41, 133-144, doi:10.1111/jbi.12204, 2014.

Murphy, B. P., Edwards, A. C., Meyer, C. P. (Mick), and RussellSmith, J.: Carbon Accounting and Savanna Fire Management, CSIRO Publishing, Melbourne, 2015a.

Murphy, B. P., Liedloff, A. C., and Cook, G. D.: Does fire limit tree biomass in Australian savannas? Int. J. Wildland Fire, 24, 1-13, doi:10.1071/WF14092, 2015b.

Neill, C., Piccolo, M. C., Cerri, C. C., Steudler, P. A., and Melillo, J. M.: Soil solution nitrogen losses during clearing of lowland Amazon forest for pasture, Plant Soil, 281, 233-245, doi:10.1007/s11104-005-4435-1, 2006.

Petheram, C., McMahon, T. A., and Peel, M. C.: Flow characteristics of rivers in northern Australia: Implications for development, J. Hydrol., 357, 93-111, doi:10.1016/j.jhydrol.2008.05.008, 2008.

Petheram, C., McMahon, T. A., Peel, M. C., and Smith, C. J.: A continental scale assessment of Australia's potential for irrigation, Water Resour. Manag., 24, 1791-1817, doi:10.1007/s11269-0099525-z, 2009.

Petheram, C., Gallant, J., Wilson, P., Stone, P., Eades, G., Roger, L., Read, A., Tickell, S., Commander, P., Moon, A., McFarlane, D., and Marvanek, S.: Northern rivers and dams: a preliminary assessment of surface water storage potential for northern Australia, CSIRO Land and Water Flagship Technical Report, Canberra, 2014.

Reichstein, M., Falge, E., Baldocchi, D., Papale, D., Aubinet, M., Berbigier, P., Bernhofer, C., Buchmann, N., Gilmanov, T., Granier, A., Grunwald, T., Havrankova, K., Ilvesniemi, H.,
Janous, D., Knohl, A., Laurila, T., Lohila, A., Loustau, D., Matteucci, G., Meyers, T., Miglietta, F., Ourcival, J.-M., Pumpanen, J., Rambal, S., Rotenberg, E., Sanz, M., Tenhunen, J., Seufert, G., Vaccari, F., Vesala, T., Yakir, D., and Valentini, R.: On the separation of net ecosystem exchange into assimilation and ecosystem respiration: review and improved algorithm, Glob. Change Biol., 11, 1424-1439, doi:10.1111/j.1365-2486.2005.001002.x, 2005.

Richards, G. P. and Evans, D. M. W.: Development of a carbon accounting model (FullCAM Vers. 1.0) for the Australian continent, Austral. For., 67, 277-283, doi:10.1080/00049158.2004.10674947, 2004.

Rose, D.: The dynamics of coarse woody debris in the mesic tropical savannas of the Darwin region: abundance, decomposition and consumption by fire, Honours Thesis, Charles Darwin University, 2006.

Russell-Smith, J., Whitehead, P. J., Cooke, P. M., and Yates, C. P.: Challenges and opportunities for fire management in fire-prone northern Australia, in Culture, Ecology and Economy of Fire Management in North Australian Savannas, edited by: RussellSmith, J., Whitehead, P. J., and Cooke, P. M., 1-23, CSIRO Publishing, Melbourne, 2009a.

Russell-Smith, J., Murphy, B. P., Meyer, C. P. (Mick), Cook, G. D., Maier, S., Edwards, A. C., Schatz, J., and Brocklehurst, P.: Improving estimates of savanna burning emissions for greenhouse accounting in northern Australia: limitations, challenges, applications, Int. J. Wildland Fire, 18, 1-18, doi:10.1071/WF08009, 2009b.

Russell-Smith, J., Cook, G. D., Cooke, P. M., Edwards, A. C., Lendrum, M., Meyer, C. P. (Mick), and Whitehead, P. J.: Managing fire regimes in north Australian savannas: applying Aboriginal approaches to contemporary global problems, Front. Ecol. Environ., 11, e55-e63, doi:10.1890/120251, 2013.

Sakai, R. K., Fitzjarrald, D. R., Moraes, O. L. L., Staebler, R. M., Acevedo, O. C., Czikowsky, M. J., da Silva, R., Braitt, E., and Miranda, V.: Land-use change effects on local energy, water, and carbon balances in an Amazonian agricultural field., Glob. Change Biol., 10, 895-907, doi:10.1111/j.15298817.2003.00773.x, 2004.

Sanderman, J., Farquharson, R., and Baldock, J. A.: Soil carbon sequestration potential: a review for Australian agriculture, Report to the Australian Department of Climate Change, Adelaide, 2010.

Steffan, W. and Hughes, L.: The Critical Decade 2013: Climate change science, risks and response, Climate Commission Secretariat, Department of Industry, Innovation, Climate Change, Science, Research and Tertiary Education, Canberra, 2013.

Surawski, N. C., Sullivan, A. L., Roxburgh, S. H., and Cook, G. D.: Review of FullCAM forest fire event parameters with recommendations supported by a literature review, CSIRO Ecosystems Science, Canberra, 2012.

Thackway, R. A.: A vegetation fuel type map for Australia's northern savannas, Department of the Environment, Canberra, 2014.

Tian, H., Chen, G., Lu, C., Xu, X., Ren, W., Zhang, B., Banger, K., Tao, B., Pan, S., Liu, M., Zhang, C., Bruhwiler, L., and Wofsy, S.: Global methane and nitrous oxide emissions from terrestrial ecosystems due to multiple environmental changes, Ecosyst. Heal. Sustain., 1, 1-20, doi:10.1890/EHS14-0015.1, 2015.

Tubiello, F. N., Salvatore, M., Ferrara, A. F., House, J., Federici, S., Rossi, S., Biancalani, R., Condor Golec, R. D., Jacobs, H., 
Flammini, A., Prosperi, P., Cardenas-Galindo, P., Schmidhuber, J., Sanz Sanchez, M. J., Srivastava, N., and Smith, P.: The contribution of agriculture, forestry and other land use activities to global warming, 1990-2012, Glob. Change Biol., 21, 26552660, doi:10.1111/gcb.12865, 2015.

van der Werf, G. R., Randerson, J. T., Giglio, L., Collatz, G. J., Mu, M., Kasibhatla, P. S., Morton, D. C., DeFries, R. S., Jin, Y., and van Leeuwen, T. T.: Global fire emissions and the contribution of deforestation, savanna, forest, agricultural, and peat fires (19972009), Atmos. Chem. Phys., 10, 11707-11735, doi:10.5194/acp10-11707-2010, 2010.

Walsh, D., Russell-Smith, J., and Cowley, R.: Fire and carbon management in a diversified rangelands economy: research, policy and implementation challenges for northern Australia, Rangel. J., 36, 313-322, doi:10.1071/RJ13122, 2014.

Weitz, A. M., Veldkamp, E., Keller, M., Neff, J., and Crill, P. M.: Nitrous oxide, nitric oxide, and methane fluxes from soils following clearing and burning of tropical secondary forest, J. Geophys. Res., 103, 28047, doi:10.1029/98JD02144, 1998.

Whitehead, P. J., Russell-Smith, J., and Yates, C.: Fire patterns in north Australian savannas: extending the reach of incentives for savanna fire emissions abatement, Rangel. J., 36, 371-388, 2014.
Williams, R. J., Zerihun, A., Montagu, K. D., Hoffman, M., Hutley, L. B., and Chen, X.: Allometry for estimating aboveground tree biomass in tropical and subtropical eucalypt woodlands: towards general predictive equations, Aust. J. Bot., 53, 607-619, doi:10.1071/BT04149, 2005.

Woinarski, J., Mackey, B., Nix, H., and Traill, B.: The nature of Northern Australia: it's natural values, ecological processes and future prospects, ANU E Press, Canberra, 2007.

Wolf, S., Eugster, W., Potvin, C., and Buchmann, N.: Strong seasonal variations in net ecosystem $\mathrm{CO}_{2}$ exchange of a tropical pasture and afforestation in Panama, Agr. Forest Meteorol., 151, 1139-1151, doi:10.1016/j.agrformet.2011.04.002, 2011.

Zenone, T., Chen, J., Deal, M. W., Wilske, B., Jasrotia, P., Xu, J., Bhardwaj, A. K., Hamilton, S. K., and Philip Robertson, G.: $\mathrm{CO}_{2}$ fluxes of transitional bioenergy crops: effect of land conversion during the first year of cultivation, GCB Bioenergy, 3, 401-412, doi:10.1111/j.1757-1707.2011.01098.x, 2011.

Zona, D., Janssens, I. A., Aubinet, M., Gioli, B., Vicca, S., Fichot, R., and Ceulemans, R.: Fluxes of the greenhouse gases $\left(\mathrm{CO}_{2}\right.$, $\mathrm{CH}_{4}$ and $\mathrm{N}_{2} \mathrm{O}$ ) above a short-rotation poplar plantation after conversion from agricultural land, Agr. Forest Meteorol., 169, 100110, 2013. 